\title{
Um algoritmo eficiente para o crescimento de redes sobre o grafo aleatório completo de um sistema de regulação gênica
}

Leandro de Araújo Lima

\author{
DisSERTAÇÃO APRESENTADA \\ AO \\ Instituto De Matemática e Estatística \\ DA \\ Universidade DE SÃo Paulo \\ PARA \\ OBTENÇÃO DO TÍTULO \\ $\mathrm{DE}$ \\ Mestre em CiÊnCIAS
}

Programa: Ciência da Computação

Orientador: Prof. Dr. Junior Barrera

Durante o desenvolvimento deste trabalho o autor recebeu auxílio financeiro da CAPES Coordenação de Aperfeiçoamento de Pessoal de Nível Superior

São Paulo, 10 de agosto de 2009 


\title{
Um algoritmo eficiente para o crescimento de redes sobre o grafo aleatório completo de um sistema de regulação gênica
}

\author{
Este exemplar corresponde à redação \\ final da dissertação/tese devidamente corrigida \\ e defendida por Leandro de Araújo Lima \\ e aprovada pela Comissão Julgadora.
}

Banca Examinadora:

- Prof. Dr. Junior Barrera (orientador) - FFCLRP-USP.

- Prof. Dr. Ronaldo Fumio Hashimoto - IME-USP.

- Prof. Dr. Ricardo Zorzetto Nicoliello Vencio - FMRP-USP. 


\section{Agradecimentos}

Primeiramente, agradeço a Deus por ter me guiado nessa caminhada e por ter se mostrado tão presente me ajudando a chegar ao fim. Agradeço também aos meus pais, Fernando e Eureni, que sempre se esforçaram ao máximo para que eu e meus irmãos estudássemos em bons colégios e nunca nos deixaram faltar nada. Agradeço a meus irmãos, Gabriel e Fernanda, por serem grandes amigos e também sempre estarem ao meu lado.

Agradeço à minha noiva, Priscila Abdala, por ter me incentivado a continuar e suportou várias dificuldades junto comigo e algumas estando distante de mim. Obrigado por ter vindo morar perto de mim, em São Paulo. Obrigado também a seus familiares, Seu Abdala, Tia Regina, Amanda e Carlos, que nos apoiaram bastante.

À minha tia Maria Praciano, por ter me recebido tão bem e por todo o auxílio dado nessa nova cidade. Ao Fabrício Benevides por também ter me ajudado a encontrar o primeiro local pra morar.

Agradeço aos amigos David Martins Jr., Fabrício M. Lopes, Jesús Mena-Chalco e David S. Pires, pelo apoio seja teórico ou seja técnico, no dia-a-dia do laboratório de Bioinformática do IME-USP. Agradeço também ao Rodrigo Pimentel, administrador da rede Vision, por ter se empenhado em recuperar os arquivos danificados após problemas na rede.

Agradeço também aos amigos da Igreja Adventista do Rio Pequeno, pela acolhida e amizade. Em especial ao amigo René Rojas Rocca, que me ajudou de várias formas. Também tenho que agradecer muito aos amigos da Igreja Adventista Central de Ribeirão Preto, que me acolheram da melhor forma possível, nos meses em que passei nessa cidade.

Gostaria de agradecer também aos professores Ronaldo Hashimoto e Ricardo Vêncio, pelo cuidado ao lerem minha dissertação e pelas preciosas dicas e correções que fizeram.

Pra encerrar, gostaria de agradecer ao meu orientador Junior Barrera, pela direção dada no 
encaminhamento dessa pesquisa, e pela forma como me recebeu em Ribeirão Preto, nos últimos meses do mestrado. Também ao meu co-orientador Nestor Walter Trepode, que também foi fundamental para o andamento e conclusão da pesquisa, dando o devido amparo quanto ao uso do software por ele desenvolvido. 


\section{Resumo}

Sabe-se biologicamente que o nível de expressão dos genes está entre os fatores podem indicar o quanto estes estão em atividade em determinado momento. Avanços na tecnologia de microarray têm possibilitado medir os níveis de expressão de milhares de genes ao mesmo tempo. Esses dados podem ser medidos de maneira a formarem uma série temporal, que pode ser tratada estatisticamente para serem obtidas informações sobre as relações entre os genes. Já foram propostos vários modelos para tratar redes gênicas matematicamente. Esses modelos têm evoluído de forma a agregarem cada vez mais características das redes reais. Neste trabalho, será feita uma revisão de modelos discretos para redes de regulação gênica, primeiramente com as redes Booleanas, modelo determinístico, e depois as redes Booleanas probabilísticas e as redes genéticas probabilísticas, modelos que tratam o problema estocasticamente. Usando o último modelo citado, serão mostrados dois métodos para estimar o nível de predição entre os genes, coeficiente de determinação e informação mútua. Além de se estimar essas relações, foram desenvolvidas algumas técnicas para construir redes a partir de genes específicos, que são chamados sementes. Também serão apresentados dois desses métodos de crescimento de redes e, baseado neles, um terceiro método que foi desenvolvido neste trabalho. Foi criado um algoritmo que realiza o crescimento da rede mudando as sementes a cada iteração, agrupando estes genes em grupos com diferentes níveis de confiança, chamados camadas. O algoritmo também usa outros critérios para agregar novos genes à rede. Após a explanação desses métodos, será mostrado um software que, a partir de dados temporais de expressão gênica, estima as dependências entre os genes e executa o crescimento da rede em torno de genes que se deseje estudar. Também serão mostradas as melhorias feitas no programa. Ao final, serão apresentados alguns testes feitos com dados do Plasmodium falciparum, parasita causador da malária.

Palavras-chave: Redes gênicas probabilísticas, informação mútua média, coeficiente de determinação, crescimento de redes. 


\section{Abstract}

It's known that gene expression levels are among the factors that can show how genes are active in certain moment. Advances in microarray technology have given the possibility to measure expression

levels of thousands of genes in a certain instant of time. These data constitute time series that we can treat statistically in order to get information genes relationships. Many models were proposed to treat gene networks mathematically. These models have evolved to aggregate more and more real networks features. In this work, it is made a brief review of discrete models of regulatory genetic networks, initially Boolean networks, a deterministic model, and then probabilistic Boolean networks and probabilistic genetic networks, models that treat the problem stochastically. Using the last model cited, two methods to estimate the prediction level among genes are shown, coefficient of determination and mutual information. Besides estimating these relations, some techniques have been developed to construct networks from specific genes, that are called seeds. It will be also shown two methods of network growth and, based on these, a third method that was developed during this work. An algorithm was created, such that it grows the network changing the seeds in each iteration, grouping these genes in groups with different level of confidence, called layers. The algorithm also uses other criteria to add new genes to the network. After studying these methods, it will be shown a software that, using time series gene expression data, estimates dependences among genes and runs the network growing process around chosen genes. It is also presented the improvements made in the program. Finally, some tests using data of Plasmodium falciparum, malaria parasite, are shown.

Keywords: Probabilistic genetic networks, Mean mutual information, coefficient of determination, network growth. 


\section{Sumário}

Lista de Figuras

Lista de Tabelas

1 Introdução $\quad 1$

2 Redes Gênicas e Medidas de Expressão $\quad 5$

2.1 Redes de regulação gênica: conceituação e funções biológicas . . . . . . . . . . . . 5

2.2 Medidas de expressão gênica por microarrays . . . . . . . . . . . . . . . . . 6

2.2 .1 Tecnologia de Microarray $\ldots \ldots \ldots \ldots \ldots$

2.2 .2 Análise estatística . . . . . . . . . . . . . . . . . . 8

3 Modelagem de Redes de Regulação Gênica $\quad 11$

3.1 Classificação das Redes . . . . . . . . . . . . . . . . . . . . . . . . 11

3.2 Sistemas Dinâmicos Discretos . . . . . . . . . . . . . . . . . . 12

3.2.1 Especificação de sistemas dinâmicos discretos . . . . . . . . . . . . . . . . . . 12

3.2 .2 Redes Booleanas . . . . . . . . . . . . . . . . . . . . . . 13

3.2.3 Redes Booleanas Probabilísticas . . . . . . . . . . . . . . . 14

3.2.4 Conceitos de Processos Estocásticos . . . . . . . . . . . . . . . . . . 15

3.3 Redes Gênicas Probabilísticas . . . . . . . . . . . . . . . . . . . . 16 
4 Estimação de redes de regulação gênica $r$

4.1 Estimação de Probabilidades em PGNs . . . . . . . . . . . . . . . . . . . . . . 19

4.1.1 Probabilidades conjuntas e condicionais . . . . . . . . . . . . 20

4.2 Medidas de dependência . . . . . . . . . . . . . . . . . . . . 21

4.2.1 Informação mútua usando entropia condicional média . . . . . . . . . . . . 21

4.2 .2 Coeficiente de Determinação $(\mathrm{CoD}) \ldots \ldots \ldots \ldots \ldots$

4.2 .3 Métodos de estimação de erro . . . . . . . . . . . . . . . . . . . 23

4.3 Modelo trivial de construção de redes . . . . . . . . . . . . . . . . 27

4.4 Modelo de crescimento de redes de E.R. Dougherty e R.F. Hashimoto . . . . . . . . 27

4.4 .1 Força de conexão . . . . . . . . . . . . . . . . . . . 27

4.4 .2 Algoritmo . . . . . . . . . . . . . . . . 28

4.5 Modelo de crescimento de redes de E.R. Dougherty e N.W. Trepode . . . . . . . . . . 29

4.5.1 Força de conexão . . . . . . . . . . . . . . . . . . . 29

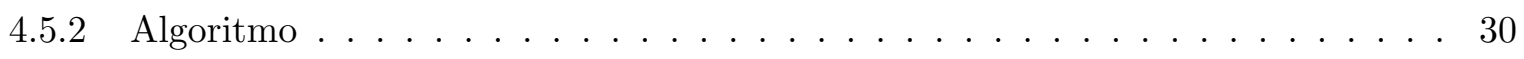

5 Contribuições para o software de estimação e crescimento de redes 33

5.1 O software de Nestor Walter Trepode . . . . . . . . . . . . . . . . . 33

5.1 .1 Estimação das dependências . . . . . . . . . . . . . . . . . 33

5.1 .2 Eliminação de redundâncias . . . . . . . . . . . . . . . . 35

5.1 .3 Ordenação dos arquivos . . . . . . . . . . . . . . . 35

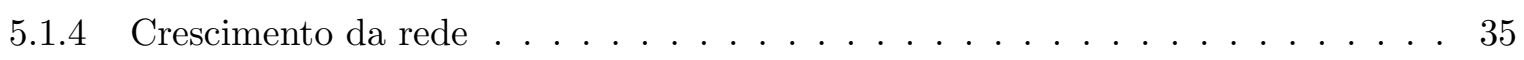

5.2 Limitações do software . . . . . . . . . . . . . . . . . . . 36

5.3 Aperfeiçoamentos . . . . . . . . . . . . . . . . 36

$6 \quad$ Algoritmo proposto para crescimento de redes $\quad 39$ 
6.1 Avanços do algoritmo proposto em relação aos anteriores . . . . . . . . . . . . . 39

6.1 .1 Diminuição do espaço de busca a cada iteração . . . . . . . . . . . . . . . . 40

6.1.2 Grau de confiança determinado por camadas . . . . . . . . . . . . . . . 44

6.1 .3 Critério para adicionar genes à rede . . . . . . . . . . . . . . 45

6.2 Algoritmo . . . . . . . . . . . . . . . . . . . . . . . 47

6.3 Implementação do algoritmo proposto . . . . . . . . . . . . . . . . . . . . . 47

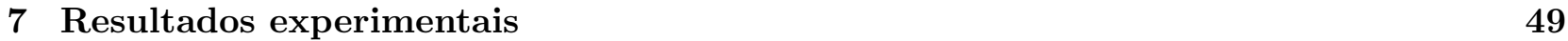

7.1 Experimentos do CAMDA . . . . . . . . . . . . . . . . . . . 49

7.2 Experimentos com algoritmo proposto . . . . . . . . . . . . . 50

8 Conclusões $\quad 59$

$\begin{array}{ll}\text { Referências Bibliográficas } & 61\end{array}$ 


\section{Lista de Figuras}

2.1 Representação simplificada de uma rede de regulação gênica. Primeiramente o processo de produção de RNA a partir do DNA (transcrição), seguido pelo processo de fabricação das proteínas a partir do RNA (tradução). A produção de proteínas envia sinais de realimentação aos processos de transcrição (seta 1) e tradução (seta 2). Também são enviados (seta 3) e recebidos (seta 4) sinais para as vias metabólicas, a partir das proteínas (Figura retirada de $[19]) \ldots \ldots \ldots \ldots$

2.2 Exemplo de dependências em uma rede gênica. Setas $(\rightarrow)$ representam relações de ativação e traços $(\dashv)$ representam relações de inibição. . . . . . . . . . . . . . . . . 7

2.3 Processo de criação das amostras de microarray com dois canais (two-channel). Reti-

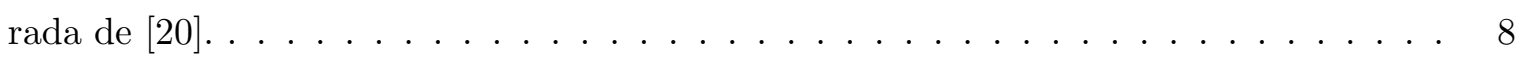

2.4 Lâmina de microarray com dois canais, no final do processo. (Retirada de http:

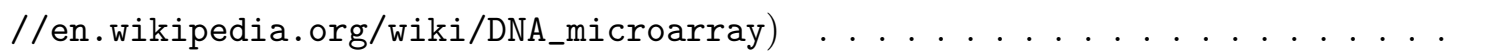

3.1 Transições de estado no exemplo dado de rede Booleana. Cada estado só muda para um único outro. O sistema entra em equilíbrio ao alcançar o estado 110 . . . . . . . . 14

5.1 Diagrama mostrando as fases de todo o processo de estimação e crescimento de redes gênicas usando o sofware de N.W. Trepode para estimar as dependências. . . . . . . . 34

6.1 Rede mostrando como são visitadas/calculadas as arestas (relações de predição) a cada iteração do algoritmo. O vértice $\mathrm{A}$, de cor laranja, representada a camada 0 . Os vértices azuis a camada 1 e os vermelhos a camada $2 \ldots \ldots$. . . . . . . . . . . 41 
6.2 Sequência de 3 iterações, comparando a busca por genes candidatos, nos algoritmos antigos e no algoritmo proposto. . . . . . . . . . . . . . . . . . . . . 43

6.3 Pequena rede com 5 genes e as respectivas relações de dependência (forças de conexão) entre o gene semente $\left(X_{0}\right)$ e o restante da rede. As arestas azuis mostram as relações de predição com prioridade maior, para os métodos de crescimento de redes antigo. As arestas vermelhas indicam as que têm prioridade maior no novo algoritmo. . . . . . 46

7.1 Grafo gerado pelo software de crescimento de redes a partir de sementes da glicólise (amarelos), usando 2 camadas e agrupando os 10 melhores grupos. . . . . . . . . . . 52

7.2 Rede crescida a partir de sementes da glicólise, usando 2 camadas e agrupando os 20 melhores grupos. . . . . . . . . . . . . . . . . . . . . . 5 . 53

7.3 Rede crescida a partir de sementes do apicoplasto (verdes). Aqui, como em alguns outros grafos gerados, houve o aparecimento natural de genes atratores. . . . . . . . . 54

7.4 Rede crescida a partir de sementes da glicólise (amarelos) e do apicoplasto (verdes). Vemos aqui que genes de apicoplasto tendem a ter ligações mais fortes entre si e com o restante da rede. . . . . . . . . . . . . . . . . . . . . . 55

7.5 Rede crescida a partir de uma semente do apicoplasto ("PLSU"), com 3 camadas, e melhores empatados sendo agregados. Observe que a camada 1 só contem dois genes, e somente um deles foi o responsável por agregar todos os genes da camada 2 ("C41" e "F13784_1"), que conseguiu recuperar um outro gene de apicoplasto ("Prps7"). . . . 56

7.6 Rede crescida a partir de uma semente do glicólise (genes "I13056_1", mais à esquerda da rede), com 3 camadas, e melhores empatados sendo agregados. Como na Fig. 7.5, somente dois genes foram agregados à segunda camada (um deles o gene central da figura, "oPFF72419"). Podemos observar aqui que na terceira camada, de número 2, seis outros genes da glicólise foram recuperados. . . . . . . . . . . . . . . . . . . 57 


\section{Lista de Tabelas}

3.1 Tabelas representando as funções de transição dos genes. Para cada configuração dos preditores no instante de tempo anterior, tem-se apenas uma possibilidade de configuração para o alvo no instante de tempo atual. . . . . . . . . . . . . . . . . 13

4.1 Medidas temporais de 3 genes, em 10 instantes de tempo. . . . . . . . . . . . . . 20

4.2 Tabelas de probabilidades conjuntas e condicionais, respectivamente, onde $x_{1}$ representa o valor de $g_{1}$ e $x_{2}$ representa o valor de $g_{2} \ldots \ldots \ldots \ldots \ldots$

5.1 Resumo das modificações no software de N.W. Trepode. . . . . . . . . . . . . . . 37

6.1 Tabela mostrando, para a rede de 5 genes, que genes seriam adicionados à rede para cada função utilizada e como ficariam as sementes na próxima iteração. . . . . . . . . . 46 


\section{Capítulo 1}

\section{Introdução}

As funções celulares são reguladas por um processo que consta de 3 fases principais: replicação do DNA, transcrição e tradução. Estas fases se intercomunicam através de seus produtos finais, que funcionam como sinais que alimentam novos ciclos desse processo.

A transcrição ou não de um gene é, em geral, determinada pela presença ou ausência de outros produtos dos genes (especialmente proteínas). Estes tipos de interações entre os genes formam redes que podem ser muito complexas, mas há diversas maneiras de fazer sua modelagem. Em nosso estudo, estamos interessados em descobrir quais genes afetam a expressão de outros e vamos trabalhar com as medidas de expressão gênica de um grupo de genes (que chamamos de rede gênica) em diferentes instantes de tempo.

A dependência e evolução temporais permitem tratar como sistemas dinâmicos essas complexas redes. Aqui iremos mostrar alguns modelos e técnicas para identificação dessas redes. Um objetivo importante de se estudar o comportamento das redes gênicas é descobrir genes que determinam fenótipos específicos (para identificar doenças, por exemplo) e modelar a atividade desses genes de maneira que possamos identificar se seu comportamento é normal ou anormal. Isso tornará possível à medicina desenvolver terapias baseadas na ruptura ou na atenuação de funções de genes aberrantes, isto é, expressos de forma irregular, para o tratamento de doenças.

Entre as fases de transcrição (formação do RNA a partir do DNA) e tradução (produção de proteínas a partir de moléculas de RNA), toma-se uma amostra de RNA para medir o nível de expressão dos genes. Através de um método chamado microarray, é possível medir o nível de expressão de milhares de genes simultaneamente. 
Com os dados obtidos através desse processo, modelamos a rede como um sistema dinâmico discreto. Estudaremos a evolução de modelos com essas características. Iremos mostrar primeiramente as redes Booleanas, totalmente determinísticas, e sua evolução para as redes Booleanas probabilísticas, que já lidam melhor com a aleatoriedade, e por isso, se aproxima mais do modelo real. Por último, o modelo utilizado para nossos experimentos, as redes gênicas probabilísticas (ou PGNs, do inglês Probabilistic Genetic Networks). Estas são uma generalização de redes Booleanas probabilísticas para sinal n-ário; aqui as redes gênicas são representadas por processos estocásticos com características bem particulares.

Escolhido o modelo a ser usado, estudaremos as formas de estimar as redes de regulação gênica. Para isso, mostraremos duas medidas de dependência, a informação mútua $[17,18]$ e o coeficiente de determinação (ou CoD, do termo em inglês "Coefficient of Determination") [1]. Estas são duas maneiras de calcular a força de predição entre os genes. Ou seja, para cada gene, essas medidas nos dizem qualitativamente quais genes os influenciam e quais são influenciados por eles. Após o cálculo dessas relações de dependência, um algoritmo de crescimento de redes é aplicado para obtermos as subredes mais robustas (isto é, genes com melhores relações de predição) em torno dos genes de nosso interesse. No método que usa coeficiente de determinação, mostramos dois métodos de estimação de erro: a ressubstituição e o leave-one-out (caso particular da validação cruzada).

Parte dos métodos apresentados foram aplicados em dados biológicos reais do parasita da malária, obtidos pela equipe de DeRisi [21]. Os dados consistem de amostras temporais, com intervalos de 1h, de 6532 genes. Antes de serem usados, os dados precisaram passar por um pré-processamento, mais precisamente normalização e quantização. Após serem calculadas as relações de dependência usando informação mútua, foram crescidas redes em torno de genes relacionados às vias metabólicas da glicólise e do apicoplasto, para compararmos nosso modelo com os experimentos realizados pela equipe vencedora do CAMDA (Critical Assessment of Microarray Data Analysis) 2004.

Para o crescimento de redes, apresentaremos dois modelos, baseados em agregação de genes por somatório de forças, em que se prioriza o aumento da autonomia da rede. O primeiro, desenvolvido por R.F. Hashimoto e E.R. Dougherty [15], usa como base as redes Booleanas probabilísticas e agrega à rede um gene de cada vez. O segundo, que é uma adaptação e melhoria do anterior e desenvolvida por E.R. Dougherty e N.W. Trepode (ainda não publicado) para ser usada em redes gênicas probabilísticas, pode agregar à rede vários genes a cada iteração, incluindo outros genes que sejam bons preditores ou bons alvo de genes da rede, e juntamente com eles, os co-preditores que participarem de cada predição. Os dois problemas principais desses algoritmos são: (1) o fato de, pelo 
critério de autonomia da rede, deixarem genes com boa predição para fora enquanto são agregados genes com uma soma boa de forças não tão boas, e (2) acumularem a semente a cada iteração e, assim, aumentando a quantidade de cálculo para encontrar os próximos genes a serem agregados.

Durante a pesquisa, propusemos um terceiro modelo para crescimento de redes baseado em algumas ideias não usadas nos algoritmos anteriores. O objetivo principal é, em torno de genes sementes, recuperar a melhor subrede possível (usando um melhor critério de agregação) sem precisar refazer cálculos desnecessariamente e, baseando-se em conceitos de grafos aleatórios, diferenciar o nível de confiança para cada gene agregado.

Nesse algoritmo, os genes adicionados à rede em cada iteração são colocados em uma camada. Cada camada agregada após a semente inicial contém os melhores genes possíveis relacionados à camada anterior. Diferenciando os genes dessa forma, precisamos fazer menos cálculos para a agregação de novos genes, já que não precisamos olhar para toda a rede. E assim, também conseguimos distinguir os genes agregados com maior ou menor grau de confiança. Baseado na ideia de caminhos sobre grafos aleatórios, podemos afirmar que genes em camadas mais distantes da semente inicial têm uma probabilidade menor se serem agregados do que os mais próximos.

O critério para se adicionar genes, como já foi dito, também foi modificado. Para se recuperar a melhor rede, olhamos cada força de conexão (de fora da rede para dentro e da rede para fora) isoladamente. Aqui estamos priorizando os genes com força máxima alta, em vez de considerarmos importantes os genes que tenham um somatório de forças alto. Dessa maneira, se um gene é um alvo (ou preditor) muito bom de algum gene da rede, ele sempre levará vantagem sobre os que são alvos e preditores razoavelmente bons, simultaneamente.

Depois da implementação do método proposto, aplicamos aos mesmos dados usados no CAMDA 2004. Levamos em conta o fato de que a equipe vencedora desse concurso também usou o método das PGNs para recuperar a arquitetura da rede do parasita da malária. Foram feitos testes com genes relacionados à glicólise e ao apicoplasto, para efeito de comparação.

No capítulo 2, daremos a conceituação biológica das redes de expressão gênica. Sua importância no mecanismo de regulação do ciclo celular, sua arquitetura. Também falaremos sobre o método microarray $[4,13]$ de medição da expressão. No capítulo 3, falaremos sobre alguns modelos de redes de regulação gênica: as redes Booleanas, as redes Booleanas probabilísticas e as redes gênicas probabilísticas, dando mais ênfase à última. No capítulo 4, falaremos sobre estimação das redes de regulação gênica usando coeficiente de determinação com dois métodos de estimação de erro e usando 
informação mútua. Também mostraremos os métodos de crescimento de redes desenvolvidos por E.R. Dougherty e R.F. Hashimoto, e E.R. Dougherty e N.W. Trepode, respectivamente. No capítulo 5, explicaremos o funcionamento do software desenvolvido por E.R. Dougherty e N.W. Trepode, bem como as modificações feitas para sua melhoria. Em seguida, no capítulo 6, mostraremos o novo algoritmo para crescimento de redes, seus conceitos e a comparação com os algoritmos anteriores. Também mostraremos alguns experimentos realizados com os dados reais de parasita da malária com o software baseado no algoritmo proposto e a comparação dos resultados com os que foram obtidos no CAMDA 2004. Finalmente, encerramos nosso texto no capítulo 8 com a conclusão do trabalho e a apresentação de perspectivas futuras. 


\section{Capítulo 2}

\section{Redes Gênicas e Medidas de Expressão}

Neste capítulo, iremos mostrar a base biológica de redes de regulação gênica. Na seção 2.1, falaremos sobre a importância e o funcionamento das redes. Também iremos exemplificar e mostrar a arquitetura de uma rede gênica. Na seção 2.2 falaremos sobre uma técnica para a obtenção de dados temporais das redes gênicas, e como os dados gerados a partir desse experimento são manipulados para a identificação das redes.

\subsection{Redes de regulação gênica: conceituação e funções biológicas}

Uma rede de regulação gênica ou rede gênica regulatória é uma coleção de segmentos de DNA em uma célula que interagem entre si (indiretamente através do seu RNA e dos produtos das proteínas) e outras substâcias dentro das células. Dessa forma, controlam as taxas de quais genes serão transcritos para RNA mensageiro (ou mRNA). Falhas neste controle, podem resultar num crescimento celular desregulado, gerando doenças como o câncer, por exemplo.

Para nosso estudo, são mais importantes as fases de transcrição e tradução, que formam a expressão gênica. Na transcrição, o DNA produz mRNA. O mRNA fabricado na transcrição produz então proteínas, através da tradução. Essas proteínas formam complexos multiprotéicos, que interagem entre si, integram sinais extracelulares e atuam na regulação das vias metabólicas, recebendo e enviando sinais de realimentação. Nesta rede, o nível de expressão de cada gene depende tanto do valor de sua própria expressão quanto dos valores da expressão de outros genes em instantes de tempo passados, além de estímulos externos.

Um gene A pode ativar ou desligar um gene B. Esse mesmo gene B pode aumentar ("upregulate") ou diminuir ("downregulate") a expressão de um outro gene C. Dessa forma, modificações em um 


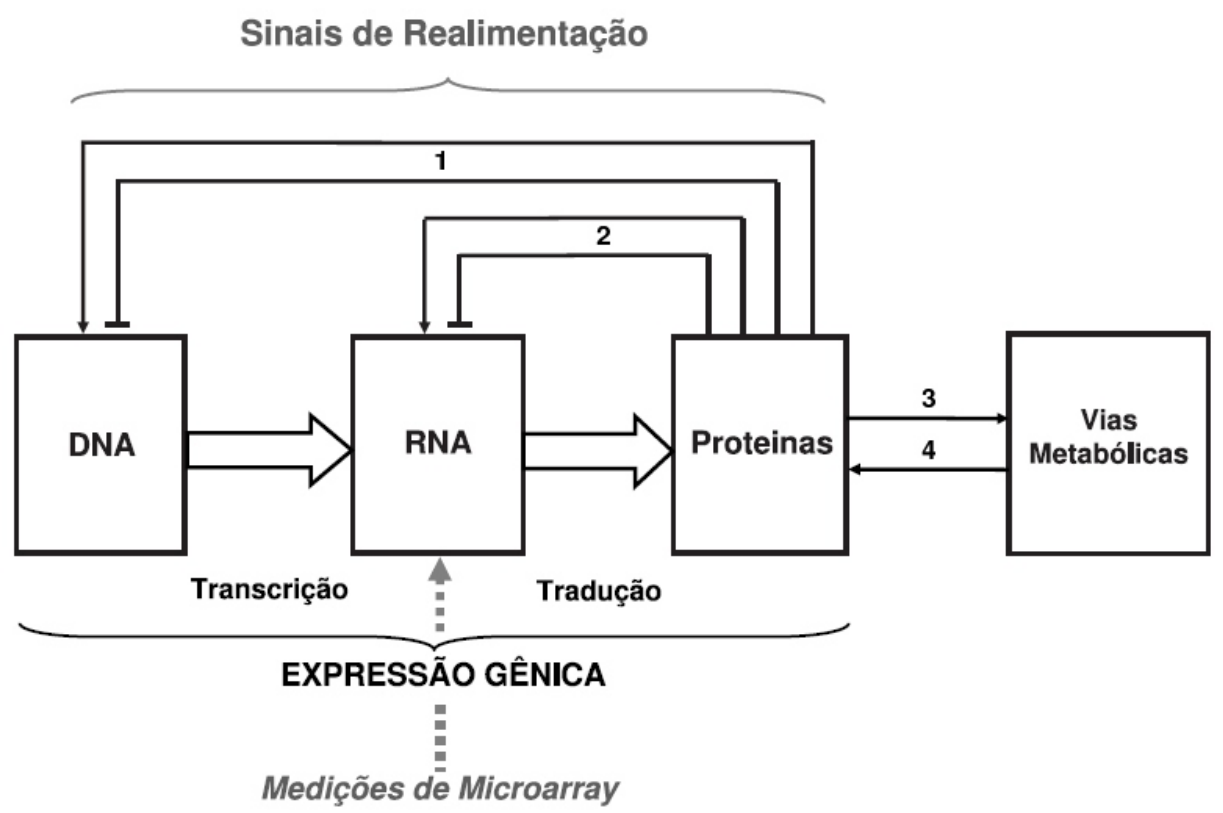

Figura 2.1: Representação simplificada de uma rede de regulação gênica. Primeiramente o processo de produção de RNA a partir do DNA (transcrição), seguido pelo processo de fabricação das proteínas a partir do RNA (tradução). A produção de proteínas envia sinais de realimentação aos processos de transcrição (seta 1) e tradução (seta 2). Também são enviados (seta 3) e recebidos (seta 4) sinais para as vias metabólicas, a partir das proteínas (Figura retirada de [19])

único gene podem causar mudanças na expressão de vários genes. A figura 2.2 mostra uma pequena rede com as dependências de inibição e ativação entre os genes.

\subsection{Medidas de expressão gênica por microarrays}

\subsubsection{Tecnologia de Microarray}

Uma das maneiras de medir o nível de expressão dos genes é a tecnologia de microarray. Iremos abordar seu funcionamento devido ao fato de termos usado dados reais obtidos por essa técnica. No entanto, os modelos e algoritmos mostrados nos próximos capítulos deste trabalho podem ser aplicados a outros métodos que gerem dados temporais de expressão genica. 


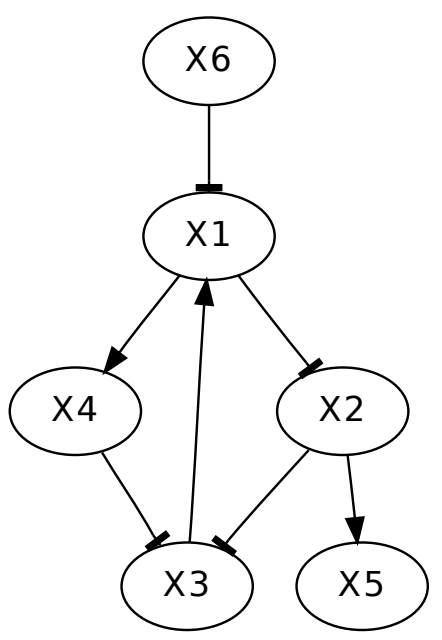

Figura 2.2: Exemplo de dependências em uma rede gênica. Setas $(\rightarrow)$ representam relações de ativação e traços $(-1)$ representam relações de inibição.

Para obter dados de vários genes em instantes de tempo seqüenciais, contamos com a tecnologia de microarray [4,9,13]. O processo (fig. 2.3) se inicia com a utilização de um braço mecânico de alta precisão que deposita pequenas quantidades de DNA em uma lâmina de vidro ou nylon (chamada chip), formando uma imensa matriz de pontos. Em seguida, utiliza-se duas amostras de mRNAs cultivados em condições distintas (no caso em que se deseje comparar amostras, chamado de "twochannel microarray"). Ambas serão submetidas ao processo de transcrição reversa (ou seja, fabricação de cDNA a partir do mRNA). Porém, elas serão marcadas de maneiras (colorações) diferentes, para que posteriormente possamos diferenciar o quanto os genes são expressos em cada condição. É bem usual que uma das amostras seja marcada com o fluorocromo cianina 3 ( $C y 3$, de cor verde) e a outra com cianina 5 (Cy5, de cor vermelha).

Após isso, mistura-se essas amostras de cDNA (marcados com as diferentes colorações) com o DNA que está na lâmina, para que haja hibridização (ligação entre as cadeias do cDNA com cadeias do DNA). Dessa forma, só formarão ligações as cadeias de cDNA fabricadas a partir de cadeias mRNA similares às cadeias de DNA que estão no vidro. Em seguida, com a captação da fluorescência das 


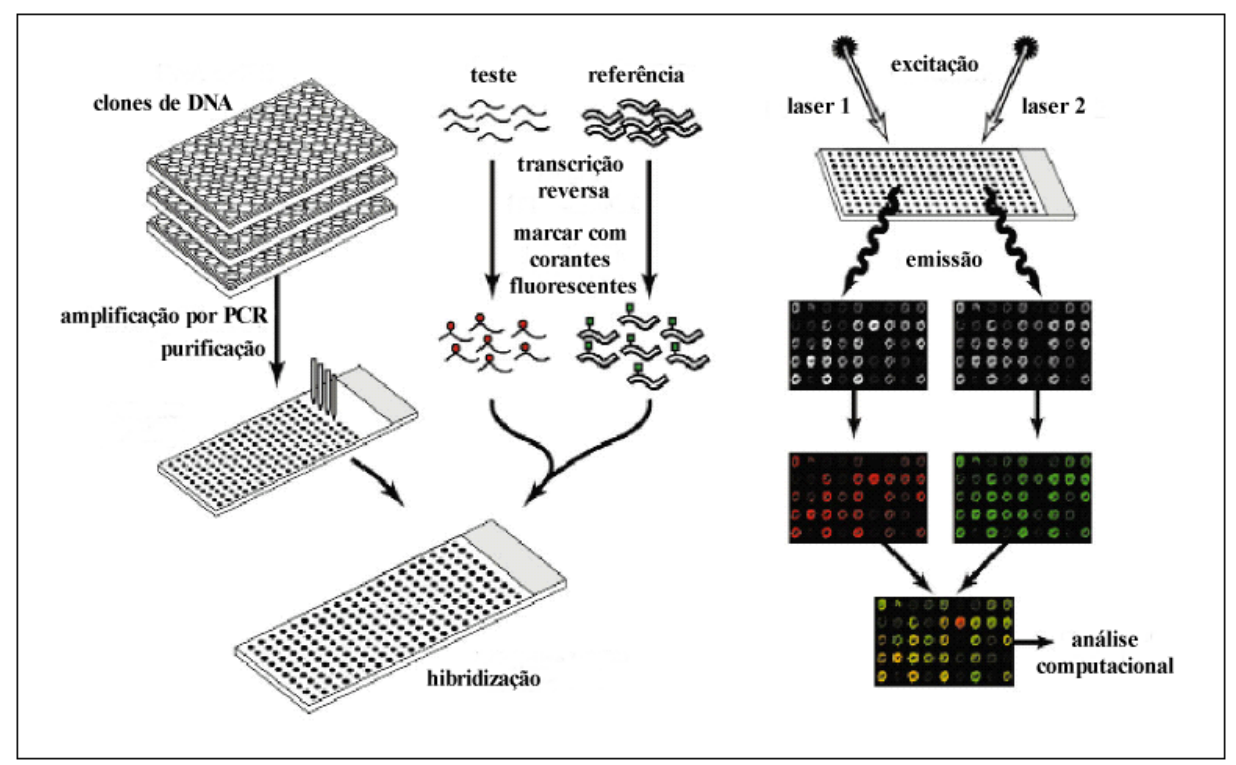

Figura 2.3: Processo de criação das amostras de microarray com dois canais (two-channel). Retirada de [20].

amostras usando laser, é possível fazer a medição de quanto cDNA ficou ligado a cada spot (ponto da lâmina de vidro), utilizando-se técnicas de análise de imagens. A figura 2.4 mostra em detalhes a lâmina e os spots após a conclusão do processo. No caso de microarray com canal único ("onechannel" ou "single-channel"), os arrays são feitos de forma a dar a estimação dos níveis absolutos da expressão dos genes. Como uma só coloração é usada, os dados obtidos representam valores absolutos da expressão gênica. Estes deverão ser comparadas com outros genes da amostra ou com amostras de referência para normalização de forma a calibrar os dados através do próprio array e através de arrays diferentes.

\subsubsection{Análise estatística}

Obtidos os dados pelo método de microarray, precisamos pré-processá-los para podermos aplicar o modelo estudado. Para isso, o sinal foi normalizado e quantizado. Primeiramente, os sinais são normalizados pela transformação normal $\eta$ dada por, para toda variável aleatória $g(t)$, onde $g(t)$ 


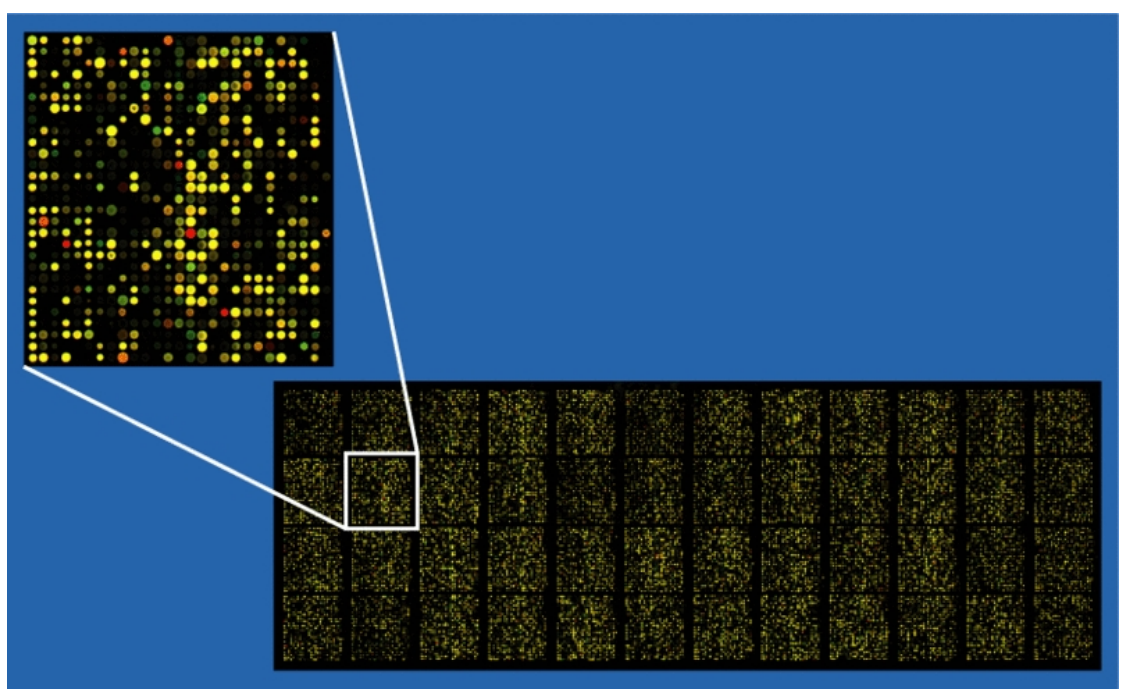

Figura 2.4: Lâmina de microarray com dois canais, no final do processo. (Retirada de http://en.wikipedia. org/wiki/DNA_microarray)

representa o nível de expressão de um gene $g$ no instante de tempo $t$,

$$
\eta[g(t)]=\frac{g(t)-E[g(t)]}{\sigma[g(t)]},
$$

onde $E[g(t)]$ e $\sigma[g(t)]$ são, respectivamente, a esperança e o desvio padrão de $g(t)$.

A transformação normal tem duas propriedades importantes:

i) $E[\eta[g(t)]]=0$ e $\sigma[\eta[g(t)]]=1$, para toda variável aleatória $g(t)$;

ii) $\eta[g(t)]=\eta[\lambda g(t)]$, para todo número real $\lambda$.

A quantização de um gene num dado instante é o mapeamento de uma expressão contínua de razão do $\log$ nos três níveis de expressão qualitativos $\{-1,0,1\}$, respectivamente, inibido, neutro e ativado, em relação à referência. A quantização de um sinal de gene $g$ é realizada por um mapeamento de limiar dado por 


$$
g^{\prime}(t)=\left\{\begin{array}{l}
+1, \text { se } g(t) \geq h \\
0, \text { se } l \leq g(t) \leq h \\
-1, \text { se } g(t) \leq l
\end{array}\right.
$$

para todo $t \geq 0$, onde $l=\frac{\sum_{g(t)<0} g(t)}{|\{g(t): g(t)<0\}|}$ e $h=\frac{\sum_{g(t)>0} g(t)}{|\{g(t): g(t)>0\}|}$.

A normalização e a quantização têm o efeito de criar classes de equivalência entre sinais, reduzindo assim erros de estimação devidos à carência de dados. 


\section{Capítulo 3}

\section{Modelagem de Redes de Regulação Gênica}

Dada a importância da aplicação biológica e a grande complexidade do problema, vários modelos de redes de regulação gênica já foram propostos [7]. Há tanto modelos contínuos como discretos, e tanto modelos determinísticos como estocásticos. Mostraremos nesta seção uma retrospectiva histórica da evolução dos modelos discretos. Mostraremos primeiramente as redes Booleanas, que são um modelo determinístico. Em seguida, apresentaremos as redes Booleanas probabilísticas, que são uma extensão não-determinística das redes Boolenas. Finalmente, explanaremos sobre as redes gênicas probabilísticas, que são o modelo utilizado em nossa análise dos dados do parasita da malária.

\subsection{Classificação das Redes}

Uma rede determinística é um rígido sistema onde o estado de expressão gênica (nível de expressão de todos os genes considerados) em um dado instante de tempo e as interações regulatórias entre eles determinam sem ambigüidade o estado de expressão gênica do próximo instante de tempo. Em tais redes, há somente uma transição possível de um estado de expressão gênica para o próximo.

Em um sistema estocástico, um dado estado de expressão gênica pode gerar mais de um estado seguinte, por exemplo, fazendo que diferentes células de uma mesma população possam seguir um caminho de expressão gênica diferente de um estado para outro. A estocacidade permite variações significantes na seqüência de ativação e inativação dos genes.

Também podemos classificar os modelos de redes quanto ao tipo de sinal. Dessa maneira, as redes podem ser consideradas discretas ou contínuas. Iremos abordar aqui somente modelos discretos. 


\subsection{Sistemas Dinâmicos Discretos}

Os sistemas dinâmicos discretos - discretos em tempo e com escala de valores finita - também são adequados para modelar o comportamento das redes de regulação gênica. Neste modelo, um gene é representado por uma variável cujo valor é dado pelo valor da expressão do gene. Todas essas variáveis, tomadas coletivamente, são as componentes de um vetor chamado estado do sistema, pelo qual são chamadas variáveis de estado. Quando os valores de todas as variáveis de estado de um sistema são conhecidas, podemos dizer que seu estado foi especificado. O estado do sistema representa então tudo o que precisamos para saber como descrevê-lo em qualquer instante de tempo. Em nosso caso, as variáveis de estado representam o valor da expressão dos genes, e cada variável de estado tem associada uma função que calcula seu próximo valor - i.e., nível de expressão ou concentração da proteína - a partir do vetor de estado. Estas funções são as componentes de um vetor de funções, chamado função de transição do sistema, que define a transição para o próximo estado, modelando a ação conjunta dos mecanismos reais de regulação.

\subsubsection{Especificação de sistemas dinâmicos discretos}

Seja $R$ a escala de valores que as componentes de estado podem assumir. Por exemplo, $R=\{0,1\}$, em sistemas binários, $R=\{-1,0,1\}$ ou $R=\{0,1,2\}$, em sistemas de três níveis. A função de transição $\phi$, de uma rede de $N$ variáveis e memória $m$, é uma função de $R^{m N}$ em $R^{N}$. Ou seja, a função de transição $\phi$ mapeia os $m$ estados prévios $x(t-1), x(t-2), \ldots, x(t-m)$ no estado $x(t)$, onde $x(t)=\left[x_{1}(t), x_{2}(t), \ldots, x_{N}(t)\right]^{T} \in R^{N}$.

Um sistema dinâmico discreto é dado por

$$
x(t)=\phi[x(t-1), x(t-2), \ldots, x(t-m)],
$$

para todo tempo $t \geq 0$. Uma componente de $x$ é um valor $x_{i} \in R$. Os sistemas definidos desta forma são invariantes por translação no tempo, isto é, a função de transição é a mesma para todo tempo discreto $t$. A arquitetura - ou estrutura - do sistema é o diagrama de conexões que representa as dependências entre as variáveis componentes do vetor de estado. A dinâmica do sistema é a evolução temporal de vetor de estado - seqüência de valores - dada pela função de transição. 


\begin{tabular}{cc|c}
$X_{2}$ & $X_{3}$ & $X_{1}$ \\
\hline 0 & 0 & 0 \\
0 & 1 & 0 \\
1 & 0 & 1 \\
1 & 1 & 1
\end{tabular}

\begin{tabular}{cc|c}
$X_{1}$ & $X_{3}$ & $X_{2}$ \\
\hline 0 & 0 & 1 \\
0 & 1 & 1 \\
1 & 0 & 1 \\
1 & 1 & 0
\end{tabular}

\begin{tabular}{cc|c}
$X_{1}$ & $X_{2}$ & $X_{3}$ \\
\hline 0 & 0 & 1 \\
0 & 1 & 0 \\
1 & 0 & 1 \\
1 & 1 & 0
\end{tabular}

Tabela 3.1: Tabelas representando as funções de transição dos genes. Para cada configuração dos preditores no instante de tempo anterior, tem-se apenas uma possibilidade de configuração para o alvo no instante de tempo atual.

\subsubsection{Redes Booleanas}

Para criar as Redes Booleanas [11], Stuart Kauffman se inspirou nos conceitos biológicos de estabilidade e epigênese. Estabilidade é o fato de um sistema se manter constante apesar das forças que tentam perturbá-lo ou modificá-lo. O termo epigênese é relacionado à adaptação, e aqui é justamente a regulação da expressão dos genes, que são modificações transmissíveis e reversíveis, sem que haja alteração na estrutura genética, ou seja, nas sequências de DNA.

As Redes Booleanas são o tipo de rede discreta mais simples. Consistem de $n$ nós, cada um representando um gene, que pode estar expresso ou não (estados 1 ou 0 , respectivamente). A dinâmica da rede é determinada por $n$ funções booleanas (uma para cada nó). Cada função booleana recebe $k$ nós de entrada, que determinam, através de regras lógicas, o estado seguinte desse nó a partir dos estados dos nós da entrada, simulando assim a epigênese.

Esse sistema é uma máquina de estados booleana, onde as transições entre os estados são totalmente determinísticas. Após uma certa quantidade de iterações o sistema adquire um estado de equilíbrio, podendo ficar alternando periodicamente em ciclos de um ou mais estados. Na tabela 3.1, vemos um exemplo de rede Booleana com 3 genes. As funções de transição de cada gene são: $f\left(X_{1}\right)=\operatorname{NOT}\left(X_{2}\right), f\left(X_{2}\right)=\mathbf{N O T}\left(X_{1} \mathbf{A N D} X_{3}\right)$ e $f\left(X_{3}\right)=X_{2}$. A figura 3.1 mostra as transições de estados do sistema.

Este modelo é uma maneira bem simplificada de representar uma rede gênica, pois a expressão gênica tende mais a ter um comportamento contínuo que binário (nunca é um caso de tudo-ou-nada). No entanto, por muitos genes terem um comportamento biestável (muito expressos ou não expressos) o modelo binário constitui uma boa aproximação. Além disso, as redes booleanas fornecem uma estrutura na qual os genes podem ter interações complexas e mostrar o comportamento comparável 


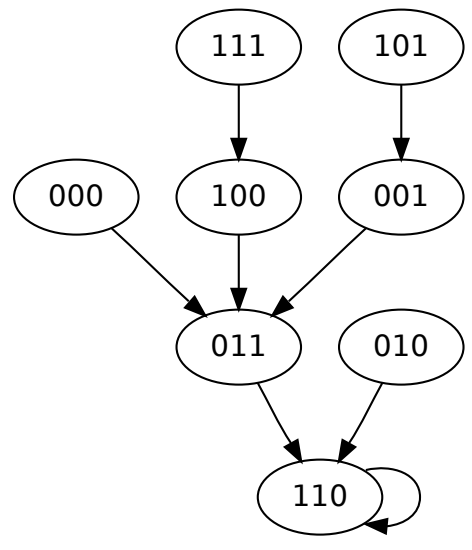

Figura 3.1: Transições de estado no exemplo dado de rede Booleana. Cada estado só muda para um único outro. O sistema entra em equilíbrio ao alcançar o estado 110.

às características das redes gênicas biológicas, por isso são um bom ponto de partida para uma modelagem realista de redes gênicas [5]. Talvez, a limitação mais evidente das redes booleanas seja seu determinismo inerente. De um ponto de vista conceitual, é provável que a regularidade das funções e interações gênicas de que se conhece a existência não é devido a regras lógicas prédefinidas, mas sim à estabilidade auto-organizável intrínseca do sistema dinâmico. De um ponto de vista empírico, a suposição de apenas uma regra lógica por gene pode induzir conclusões incorretas quando se inferem essas regras de medições de expressão gênica, ao passo que estas tipicamente têm ruídos e o número de amostras é pequeno relativo ao número de parâmetros a serem inferidos [6].

\subsubsection{Redes Booleanas Probabilísticas}

As Redes booleanas probabilísticas [6] são um modelo baseado nas Redes Booleanas, com algumas adaptações para lidar com particularidades das redes gênicas que esse modelo não é capaz de tratar.

O avanço das pesquisas em Biologia e Medicina tem mostrado que há muito mais questões a serem respondidas além do que modela o formalismo Booleano, que se atém mais a princípios genéricos que a detalhes bioquímicos quantitativos. Quanto maior for a complexidade de um organismo, maior

a incerteza envolvida. É esse ponto que limita um modelo totalmente determinístico. E ainda é 
possível que alguém queira modelar uma rede com estímulos externos, em que determinada condição faria o sistema se comportar de maneira diferente de quando estivesse na ausência desta.

O objetivo da criação das PBNs (do inglês Probabilistic Boolean Networks) foi desenvolver um método tal que:

i) incorporasse dependências entre os genes baseadas em regras;

ii) permitisse o estudo sistemático da dinâmica global da rede;

iii) tivesse a condição de lidar com a incerteza, tanto nos dados, quanto na seleção do modelo e

iv) permitisse a quantificação da influência relativa e a sensibilidade dos genes na interação com genes.

A idéia básica é extender as Redes Booleanas para que cada nó (gene) pudesse ter mais de uma função possível. Então, para cada nó $x_{i}$, há um conjunto correspondente

$$
F_{i}=\left\{f_{j}^{(i)}\right\}_{j=1, \ldots, l(i)},
$$

onde cada $f_{j}^{(i)}$ é uma função possível para determinar o valor do gene $x_{i}$ e $l(i)$ é o número possível de funções para o gene $x_{i}$.

A probabilidade de uma função $f_{j}^{(i)}$ ser usada para predizer um gene $x_{i}(1 \leq j \leq l(i))$ é igual a

$$
c_{j}^{(i)}=\operatorname{Pr}\left\{f^{(i)}=f_{j}^{(i)}\right\} .
$$

\subsubsection{Conceitos de Processos Estocásticos}

Quando a função de transição $\phi$ é uma função estocástica (isto é, para cada seqüência de estados $x(t-m), \ldots, x(t-2), x(t-1)$, o próximo estado $x(t)$ é uma realização de um vetor aleatório) o sistema dinâmico é um processo estocástico.

Quando consideramos uma situação em que são feitas observações quanto a um período de tempo e essa situação é influenciada por efeitos aleatórios, não só em um único instante, mas por todo o intervalo de tempo, chamamos essa situação de um processo estocástico. 
Em termos gerais, um processo estocástico é um fenômeno que varia em algum grau, de forma imprevisível, à medida que o tempo passa. A imprevisibilidade, nesse caso, implica que se foi observada uma seqüência de tempo inteira do processo em diversas ocasiões, sob condições presumivelmente idênticas, as seqüências em observação resultantes, seriam, em geral, diferentes.

Uma vez que um processo estocástico envolve o comportamento de um sistema durante um período de tempo, quando se define o processo, deve-se começar por especificar o conjunto de tempo $\mathrm{T}$ envolvido. Esse pode ser tanto um intervalo de tempo em uma situação na qual as medidas são tomadas continuamente, como uma seqüência de tempos, em casos onde as medições do sistema são feitas a cada intervalo de tempo. No primeiro caso, fala-se de um processo de parâmetros contínuos, e no segundo, de um processo de parâmetros discretos, que é o caso aqui considerado.

A natureza estocástica das redes gênicas é amparada tanto pela teoria quanto por resultados experimentais. Mecanismos que explicam esta estocacidade são, por exemplo, a degradação dos produtos dos genes, a colisão espacial necessária antes que um reagente possa exercer sua influência, equações de reação reversível, etc. Conseqüentemente, os modelos estocásticos descrevem a cinética da regulação gênica melhor do que uma aproximação determinística. Em geral, resultados experimentais podem ser melhor explicados e modelados por mecanismos estocásticos. Por outro lado, os modelos determinísticos são mais simples que os estocásticos.

\subsection{Redes Gênicas Probabilísticas}

Aqui, as redes de regulação gênica são representadas por processos estocásticos nos quais a função de transição estocástica é uma família particular de cadeias de Markov, chamadas redes gênicas probabilísticas $[8,10]$.

Considere uma seqüência de vetores aleatórios $X_{0}, X_{1}, X_{2}, \ldots$ que toma valores em $R^{N}$, denotados, respectivamente, $x(0), x(1), x(2), \ldots$ Uma seqüência de estados aleatórios $\left(X_{t}\right)_{t=0}^{\infty}$ é chamada uma cadeia de Markov, se para cada $t \geq 1$,

$$
P\left[X_{t}=x(t) \mid X_{0}=x(0), \ldots, X_{t-1}=x(t-1)\right]=P\left[X_{t}=x(t) \mid X_{t-1}=x(t-1)\right] .
$$

Ou seja, a probabilidade condicional do evento futuro, dada a história passada, só depende do instante de tempo anterior. Seja $X$, com realização $x$, o estado antes da transição, e seja $Y$, com realização $y$, o primeiro estado depois da transição. Uma cadeia de Markov é completamente 
caracterizada pela distribuição de probabilidades $\pi_{0}$ do vetor aleatório representando o estado inicial e pela matriz de transição $\pi_{Y \mid X}$ de probabilidades condicionais entre estados - cujos elementos são denotados $p_{y \mid x}$. A função de transição estocástica $\phi$ no tempo $t$, para todo $t \geq 1$, é dada por

$$
\phi[x]=\phi[x(t-1)]=y
$$

onde $y$ é uma realização do vetor aleatório $Y$ com distribuição $p_{\bullet} \mid x$.

Uma cadeia de Markov de ordem $m$ - a qual depende dos $m$ instantes de tempo anteriores à transição - é equivalente a uma cadeia de Markov com estados de dimensão $m \times N$.

Seja a seqüência $\mathbf{X}=X_{t-1}, \ldots, X_{t-m}$, com realização $\mathbf{x}=x(t-1), \ldots, x(t-m)$, a seqüência de $m$ estados antes da transição. Uma Rede Gênica Probabilística é uma cadeia de Markov $\left(\pi_{Y \mid X}, \pi_{0}\right)$ de ordem $m$, tal que:

i) $\pi_{Y \mid \mathbf{X}}$ é homogênea, ou seja, $p_{y \mid \mathbf{x}}$ é independente de $t$;

ii) $p_{y \mid \mathbf{x}}>0$ para todos os estados $x \in R^{m N}, y \in R^{N}$, ou seja, todas as transições de estados são possíveis (característica de um sistema ergódico);

iii) $\pi_{Y \mid \mathbf{X}}$ é condicionalmente independente, ou seja, para todos os estados $x \in R^{m N}, y \in R^{N}$,

$$
p_{y \mid \mathbf{x}}=\prod_{i=1}^{N} p\left(y_{i} \mid \mathbf{x}\right)
$$

iv) $\pi_{Y \mid \mathbf{X}}$ é quase determinística, ou seja, para toda seqüência de estados $\mathbf{x} \in R^{m N}$, existe um estado $y \in R^{N}$ tal que $p_{y \mid \mathbf{x}} \approx 1$ (esse axioma é caracterizado especialmente pela concentração da massa de probabilidade de uma predição, que deve ter valor maior ou igual a $80 \%$ ).

Essa propriedades são inspiradas em fenômenos biológicos ou simplificações para melhorar o tratamento dos dados, que geralmente estão em quantidade reduzida. A primeira propriedade, que significa que a matriz é invariante à translação no tempo, serve para simplificar o problema de estimação. No entanto, este poderia ser facilmente generalizado. A segunda determina que todos os estados sejam alcançáveis. Isso pode acontecer devido aos ruídos, que são tratados com a quarta propriedade. A terceira diz que a expressão de um gene em um dado instante de tempo independe da expressão de outros genes no mesmo instante de tempo. 
Escolhido o modelo, iremos definir a forma como estimar as relações de predição para recuperar a arquitetura de uma rede. No próximo capítulo iremos dissertar sobre isso. 


\section{Capítulo 4}

\section{Estimação de redes de regulação gênica}

Neste capítulo, falaremos sobre estimação de redes de regulação gênica a partir do método de Redes Gênicas Probabilísticas. Fazemos aqui uma comparação entre o uso do coeficiente de determinação e da informação mútua como medidas de força. Também apresentaremos o método de crescimento de redes a partir de genes sementes de E.R. Dougherty e R.F. Hashimoto [15] e o de E.R. Dougherty e N.W. Trepode (não publicado até o término deste texto). Também apresentaremos um novo algoritmo de crescimento de redes que recupera a arquitetura da rede fazendo menos cálculos que os algoritmos anteriores.

\subsection{Estimação de Probabilidades em PGNs}

Nesta seção, iremos usar uma pequena rede hipotética de 3 genes para identificar as relações de dependência entre alguns desses. A rede terá sinal binário ( 0 e 1) e em nosso exemplo usaremos 10 amostras (instantes de tempo). Para a identificação da rede, iremos usar o método do CoD (coeficiente de determinação) e a informação mútua.

Seja a tabela a seguir a medida da expressão de 3 genes de uma rede qualquer em 10 instantes sequenciais de tempo.

Usaremos aqui a predição de um gene alvo a partir dos preditores apenas no instante anterior ao seu. Ou seja, para cada instante de tempo $t_{i}$ do gene alvo analisado, utilizaremos os dados do instante tempo $t_{i-1}$ dos preditores. 


\begin{tabular}{c|cccccccccc} 
genes & $t_{1}$ & $t_{2}$ & $t_{3}$ & $t_{4}$ & $t_{5}$ & $t_{6}$ & $t_{7}$ & $t_{8}$ & $t_{9}$ & $t_{10}$ \\
\hline$g_{1}$ & 0 & 1 & 0 & 0 & 0 & 0 & 0 & 1 & 0 & 1 \\
$g_{2}$ & 1 & 1 & 0 & 0 & 0 & 1 & 1 & 1 & 1 & 1 \\
$g_{3}$ & 1 & 1 & 0 & 1 & 1 & 0 & 1 & 1 & 0 & 0
\end{tabular}

Tabela 4.1: Medidas temporais de 3 genes, em 10 instantes de tempo.

\begin{tabular}{cc|cc}
$x_{1}$ & $x_{2}$ & $P\left(g_{3}=0, g_{1}=x_{1}, g_{2}=x_{2}\right)$ & $P\left(g_{3}=1, g_{1}=x_{1}, g_{2}=x_{2}\right)$ \\
\hline 0 & 0 & $1 / 9$ & $2 / 9$ \\
0 & 1 & $1 / 9$ & $3 / 9$ \\
1 & 0 & 0 & 0 \\
1 & 1 & $2 / 9$ & 0 \\
& & & \\
$x_{1}$ & $x_{2}$ & $P\left(g_{3}=0 \mid g_{1}=x_{1}, g_{2}=x_{2}\right)$ & $P\left(g_{3}=1 \mid g_{1}=x_{1}, g_{2}=x_{2}\right)$ \\
\hline 0 & 0 & $1 / 3$ & $2 / 3$ \\
0 & 1 & $1 / 4$ & $3 / 4$ \\
1 & 0 & 0 & 0 \\
1 & 1 & 1 & 0
\end{tabular}

Tabela 4.2: Tabelas de probabilidades conjuntas e condicionais, respectivamente, onde $x_{1}$ representa o valor de $g_{1}$ e $x_{2}$ representa o valor de $g_{2}$.

\subsubsection{Probabilidades conjuntas e condicionais}

Para ambos os métodos, precisamos calcular as probabilidades conjuntas e condicionais entre $\mathrm{X}$ (vetor aleatório com os possíveis valores do preditores) e $Y$ (variável aleatória com os possíveis valores do alvo). Para isso, a partir de nossa amostra, contamos, para cada configuração (nesse caso, $[0,0],[0,1],[1,0]$ e $[1,1])$ dos preditores, a probabilidade de o gene alvo apresentar as diferentes configurações possíveis (nesse caso, 0 e 1 ).

As tabelas acima mostram a probabilidades conjuntas e condicionais para $g_{3}$ como alvo e $g_{1}$ e $g_{2}$ como preditores.

Como usamos o instante de tempo anterior, do total de 10 amostras conseguimos contabilizar apenas 9 observações. Observando a tabela de probabilidades conjuntas vemos que, das nove amostras observadas, uma apresenta a configuração $x_{t-1}\left[g_{1}=0, g_{2}=0\right], x_{t}\left[g_{3}=0\right]$, três a configuração $x_{t-1}\left[g_{1}=0, g_{2}=1\right], x_{t}\left[g_{3}=1\right]$ e assim por diante. 


\subsection{Medidas de dependência}

\subsubsection{Informação mútua usando entropia condicional média}

A entropia $H(X)$ [17] de uma variável aleatória $X$ é a medida de sua distribuição $p_{i}$, dada por

$$
H(X)=-\sum_{i=1}^{n} p_{i} \log _{n} p_{i}
$$

onde $n$, no nosso caso, é a quantidade de valores que um gene pode assumir (o tamanho do conjunto $R$, definido na seç. 3.2.1).

A entropia tem algumas propriedades notáveis:

i) Todas as distribuições formadas por permutações de $p_{i}$ têm a mesma entropia;

ii) Concentrar a massa de probabilidade de uma distribuição implica diminuir sua entropia.

Como um corolário da propriedade (ii), a distribuição uniforme apresenta entropia máxima e aquelas com entropia mínima tem a massa de probabilidade total concentrada em um único ponto.

A informação mútua entre duas variáveis aleatórias $X$ e $Y$ é a medida definida por

$$
I(X, Y)=H(Y)-H(Y \mid X)
$$

A esperança (ou valor esperado) $E[I(X, Y)]$ de $I(X, Y)$ é dado por

$$
E[I(X, Y)]=H(Y)-E[H(Y \mid X)]
$$

Quando $E[I(X, Y)]=0, X$ e $Y$ podem ser variáveis independentes e a condição $P(Y)=P(Y \mid X)$ deve ser testada. Caso esta condição seja verdade, então $X$ e $Y$ são independentes, caso contrário, elas têm dependência.

A esperança da informação mútua é usada para estimar a arquitetura da $\mathrm{PGN}^{1}$. A variável aleatória $Y$ será o valor do gene $y_{i}[t+1]$ a ser predito e a variável aleatória $\mathbf{X}$ dada será o vetor de genes $x[t]$ ponderado por um vetor $a$ de inteiros, associado ao gene $y_{i}$. Para cada vetor $a$, com

\footnotetext{
${ }^{1}$ Aqui estamos considerando PGNs como cadeias de Markov simples.
} 
$a_{i} \in-1,0,1$ e no máximo dois valores diferentes de 0 , a informação mútua média é estimada. Os primeiros vetores $a$, que têm informação mútua maior, são selecionados. Esses vetores indicam se há interação entre os genes e se a interação é de ativação ou inibição.

A partir do exemplo de rede dado, vamos calcular a entropia e a informação da predição do gene $g_{3}$ pelos genes $g_{1}$ e $g_{2}$. Primeiro, devemos calcular $H(Y)$ da seguinte forma ${ }^{2}$ :

$$
\begin{gathered}
H(Y)=-\sum_{i=0}^{1} P(y=i) \log _{2} P(y=i), \text { que nesse caso é igual a } \\
H(Y)=-(4 / 10) \log _{2}(4 / 10)-(6 / 10) \log _{2}(6 / 10)=0.970 .
\end{gathered}
$$

Devemos lembrar que a base do log é relativa à faixa de valores do sinal da rede (como aqui estamos usando sinal binário, a base do logaritmo é 2). Como pudemos observar, o valor da entropia foi bem alta, ou seja, considerada ruim por ser quase igual a 1 (uma entropia considerada de boa qualidade teria o valor próximo a 0 ). Isso indica que sem olhar o estado dos preditores $\left(g_{1}\right.$ e $\left.g_{2}\right)$, é ruim prevermos que valor o alvo $\left(g_{3}\right)$ vai ter, justamente porque nas amostras ele apareceu 4 vezes com valor 0 e 6 vezes com valor 1 , ou seja, quase empatado.

Agora, calcularemos $E[H(Y \mid \mathbf{X})]$ da seguinte forma: para cada configuração $x$ de $\mathbf{X}$, ou seja, para cada estado dos preditores (nesse caso, $x=(0,0), x=(0,1), x=(1,0)$ e $x=(1,1)$ ), calculamos a esperança da entropia multiplicando o valor de cada caso pela probabilidade $P$ de este ocorrer.

$$
\begin{gathered}
E[H(Y \mid \mathbf{X})]=\sum_{x \in X} P(\mathbf{X}=x) H(Y \mid \mathbf{X}=x), \text { onde } \\
H(Y \mid \mathbf{X}=x)=-\sum_{i=0}^{1} P(y=i \mid \mathbf{X}=x) \log _{2} P(y=i \mid \mathbf{X}=x) .
\end{gathered}
$$

Vejamos na tabela a seguir o cálculo passo a passo:

\begin{tabular}{cc|l}
$g_{1}$ & $g_{2}$ & $H(Y \mid \mathbf{X}=x)$ \\
\hline 0 & 0 & $-(1 / 3) \log _{2}(1 / 3)-(2 / 2) \log _{2}(2 / 3)=0.918$ \\
0 & 1 & $-(1 / 4) \log _{2}(1 / 4)-(3 / 4) \log _{2}(3 / 4)=0.811$ \\
1 & 0 & 0 \\
1 & 1 & $-(1) \log _{2}(1)-0=0$
\end{tabular}

\footnotetext{
${ }^{2}$ Para esse cálculo, como não estamos olhando o estado dos preditores, usamos todas as 10 amostras.
} 
Logo, $E[H(Y \mid \mathbf{X})]=\frac{3}{9} \times 0.918+\frac{4}{9} \times 0.811+0 \times 0+\frac{2}{9} \times 0=0.666$. Desse resultado, calculamos, $I(\mathbf{X}, Y)$ (a informação mútua entre $\mathbf{X}$ e $Y$ ) que é $0.970-0.666=0.304$. Já era esperado que $H(Y \mid \mathbf{X})$ fosse melhor que $H(Y)$ (ou seja, com uma valor mais próximo a 0), pois estamos estimando o valor do alvo analisando o valor do preditores, o que aumenta a quantidade de informação disponível.

\subsubsection{Coeficiente de Determinação (CoD)}

O Coeficiente de Determinação $[1,16]$ (ou CoD, do inglês "Coefficient of determination") $\theta_{1,2, \ldots, n}$ de um gene alvo $x_{t}$ por um determinado conjunto de genes preditores $x_{1}, x_{2}, \ldots, x_{n}$ pode ser definido como

$$
\theta_{1,2, \ldots, n}=\frac{\varepsilon_{0}-\varepsilon_{1,2, \ldots, n}}{\varepsilon_{0}}=1-\frac{\varepsilon_{1,2, \ldots, n}}{\varepsilon_{0}}, 0 \leq \theta_{1,2, \ldots, n} \leq 1, \text { onde: }
$$

i) $\varepsilon_{0}$ é o erro cometido ao estimar o alvo $x_{t}$ pelo seu valor médio, isto é, sem observação de outras variáveis. $\varepsilon_{0}$ é o maior - pior - erro de estimação do alvo, pois não são usadas outras informações além do valor dele mesmo nas amostras;

ii) $\varepsilon_{1,2, \ldots, n}$ é o erro cometido ao estimar o alvo $x_{t}$ a partir dos genes preditores $x_{1}, x_{2}, \ldots, x_{n}$.

O coeficiente de determinação $\theta_{1,2, \ldots, n}$ expressa a melhora relativa do erro de estimação produzida pelo uso da informação dos genes $x_{1}, x_{2}, \ldots, x_{n}$ para estimar o valor do gene alvo $x_{t}$, com referência ao erro que se teria na estimação dele sem observar outras variáveis. Se o valor do CoD se aproxima de 0 , então a observação dos genes $x_{1}, x_{2}, \ldots, x_{n}$ não contribui para a estimação do gene alvo $x_{t}$. Ao contrário, se o valor do CoD se aproxima de 1 (o caso ideal, que é o CoD ser igual a um, não acontece na prática), então os genes $x_{1}, x_{2}, \ldots, x_{n}$ estimam o valor exato de $x_{t}$, ou seja, com erro igual a zero.

$\mathrm{O} \mathrm{CoD}$ fornece uma medida objetiva da qualidade de um determinado conjunto de genes preditores para estimar um determinado gene alvo (quanto maior é o valor do CoD para uma determinada combinação preditores-alvo, menor é o erro cometido na estimação de valor do gene alvo a partir dos valores conhecidos desses genes preditores). Por isso, CoD tem sido usado amplamente para quantificar a interação entre genes, destacando na rede suas dependências mais relevantes.

\subsubsection{Métodos de estimação de erro}

Chamaremos de estimador a função que estima o valor de um gene a partir de um conjunto de valores de outros genes (que também pode conter o próprio gene). Para se estimar o erro da predição da rede, o estimador é criado (treinado) e após isso, testado, para se estimar o erro cometido. 
Vamos mostrar aqui duas maneiras de treinar e testar esses estimadores. Em cada um dos métodos, calculamos o erro da predição de um gene $x_{t}$ sem e com a observação de outros genes, para o cálculo do CoD.

\section{Ressubstituição}

Neste método, o estimador é treinado com todas as amostras e aplicado nas mesmas amostras, i.e., o conjunto de treinamento e de aplicação é o mesmo. O erro total é a média dos erros cometidos na estimação de todas as amostras.

O cálculo do erro sem observação de outros genes, representado por $\varepsilon_{0}$, se dá da seguinte forma:

i) O valor estimado do alvo $\widehat{x}_{t}$ é o valor mais observado (a moda) deste no conjunto de amostras.

ii) O erro (quadrático) sem observação é calculado como:

$$
\varepsilon_{0}=\frac{\sum_{i=1}^{n}\left(x_{t}[i]-\widehat{x}_{t}\right)^{2}}{n}, \text { onde } n \text { é o número de amostras utilizadas. }
$$

O cálculo do erro da estimação pela observação dos genes preditores, representado por $\varepsilon_{i, j, \ldots, k}$, para as combinações do número de preditores alvo que se desejar, é calculado da seguinte maneira:

i) Usando todas as amostras, é calculado o operador que estima o alvo. Para cada estado dos preditores $x_{i}, x_{j}, \ldots, x_{k}$, ele devolve o valor mais observado nas amostras que têm esse estado dos preditores.

ii) O operador obtido é aplicado no mesmo conjunto de amostras para estimar o valor do alvo em todas elas.

iii) $\mathrm{O}$ erro $\varepsilon_{i, j, \ldots, k}$ é calculado da mesma forma do erro anterior, computando-se a média ${ }^{3}$ das diferenças quadráticas entre o valor estimado e o valor observado.

Finalmente, o CoD é calculado como

$$
\theta_{i, j, \ldots, k}=1-\frac{\varepsilon_{i, j, \ldots, k}}{\varepsilon_{0}}
$$

\footnotetext{
${ }^{3}$ o valor $n$ usado para este cálculo pode ser diferente do $n$ usado no cálculo de $\varepsilon_{0}$
} 


\section{Exclusão de uma amostra}

Neste método ${ }^{4}$, o estimador é treinado após a exclusão de uma amostra do conjunto, e esta é usada para testá-lo. Isto é feito para todas as amostras do conjunto de dados e tira-se a média dos erros de estimação.

O cálculo do erro sem observação de outros genes se dá da seguinte forma, para cada amostra:

i) A amostra é excluída do conjunto de dados.

ii) O valor do gene alvo na amostra excluída é estimado como o valor mais observado deste no conjunto restante de amostras.

iii) O erro quadrático de estimar essa amostra é calculado (diferença quadrática do valor estimado ao valor do alvo na amostra excluída). O erro sem observação $\varepsilon_{0}$ é calculado como a média dos erros de estimar o alvo em todas as amostras.

O cálculo do erro da estimação pela observação dos genes preditores, para as combinações do número de preditores alvo que se desejar, é calculado da seguinte maneira:

i) A amostra é excluída do conjunto de dados e o estado dos preditores do gene alvo nessa amostra é observado.

ii) Usando as demais amostras é estimado o valor do alvo na amostra excluída como o valor mais observado do alvo quando os preditores têm o estado observado no passo anterior.

iii) O erro quadrático do valor estimado ao valor do alvo na amostra excluída é calculado. O erro $\varepsilon_{i, j, \ldots, k}$ é calculado como a média dos erros de estimar o alvo em todas as amostras - excluídas, uma por vez.

Finalmente, como no caso anterior, o CoD é calculado como

$$
\theta_{i, j, \ldots, k}=1-\frac{\varepsilon_{i, j, \ldots, k}}{\varepsilon_{0}}
$$

\footnotetext{
${ }^{4}$ também bastante conhecido pelo termo Leave-one-out, em inglês
} 
Para efeito de comparação, faremos também o cálculo de valor do $\mathrm{CoD}$ usando a mesma rede hipotética descrita na tabela 4.1. Como método de estimação de erro para o CoD, usaremos a ressubstituição.

Primeiramente, vamos calcular o erro da estimação do valor do alvo somente por seu próprio valor nas amostras. $\varepsilon_{0}$ :

i) Temos que $\widehat{x}_{t}=1$ (valor mais observado do alvo nas amostras)

ii) $\varepsilon_{0}=$

$$
\begin{aligned}
& \left((1-1)^{2}+(0-1)^{2}+(1-1)^{2}+(1-1)^{2}+(1-1)^{2}+\right. \\
& \left.(0-1)^{2}+(1-1)^{2}+(1-1)^{2}+(0-1)^{2}+(0-1)^{2}\right) / 10=4 / 10=0.4
\end{aligned}
$$

O cálculo de $\varepsilon_{i, j, \ldots, k}$ se dá da seguinte forma:

i) Temos que criar o estimador $\widehat{x}_{t}$ para o alvo analisando cada estado dos preditores nas amostras

ii) Para cada estado dos preditores, somamos o erro quadrático da diferença entre o valor real $\left(x_{t}[i]\right)$ e o esperado $\left(\widehat{x}_{t}\right)$, depois calculamos a média. Para isso, vamos contar com a ajuda da

\begin{tabular}{|c|c|c|c|c|}
\hline$t$ (amostra) & $g_{1} g_{2}$ & $x_{t}[i]$ & $\widehat{x}_{t}$ & $\left(x_{t}[i]-\widehat{x}_{t}\right)^{2}$ \\
\hline 1 & 01 & 1 & 1 & 0 \\
\hline 2 & 11 & 0 & 0 & 0 \\
\hline 3 & 00 & 1 & 1 & 0 \\
\hline 4 & 00 & 1 & 1 & 0 \\
\hline 5 & 00 & 0 & 1 & 1 \\
\hline 6 & 01 & 1 & 1 & 0 \\
\hline 7 & 01 & 1 & 1 & 0 \\
\hline 8 & 11 & 0 & 0 & 0 \\
\hline 9 & 01 & 0 & 1 & 1 \\
\hline
\end{tabular}
tabela abaixo.

Logo, temos que $\varepsilon_{i, j, \ldots, k}=2 / 9=0.222$. E o CoD é calculado como

$$
\theta_{i, j, \ldots, k}=1-\frac{0.222}{0.4}=0.445
$$




\subsection{Modelo trivial de construção de redes}

Seja $n$ a quantidade de genes para os quais desejamos construir a arquitetura de uma rede. Ao construímos redes gênicas, desejamos selecionar apenas as melhores relações de dependência. No modelo trivial, calcularíamos as dependências de todos os $n$ genes entre si, com $n-1$ combinações de preditores. Para um só gene como alvo, teríamos que calcular:

- Para 1 preditor: $C_{n, 1}$;

- Para 2 preditores: $C_{n, 2}$;

- Para $n-1$ preditores: $C_{n, n-1}$.

Isto é, calcularíamos aproximadamente $2^{n}$ dependências (uma aproximação para o somatório dos

itens acima, $\left.\sum_{i=1}^{n-1} C_{n, i}\right)$. Quando o cálculo envolve muitos genes, o que geralmente acontece em dados reais, isso fica inviável.

O que desejamos é conseguir capturar a arquitetura da rede de modo a escolher os melhores conjuntos de preditores, sem precisar fazer cálculos desnecessários. Nos métodos explicados a seguir, crescemos a rede sem precisar verificar todas as relações de predição.

\subsection{Modelo de crescimento de redes de E.R. Dougherty e R.F. Hashimoto}

A construção da subrede depende de um critério para medir a relação entre genes, uma função objetivo envolvendo este critério para decidir que genes devem ser adicionados à rede crescente e um algoritmo incorporando a função objetivo que inclui tanto as condições de inicialização quanto as de parada.

\subsubsection{Força de conexão}

Ao modelarmos uma rede gênica regulatória como um grafo direcionado, denotamos a força de conexão de um conjunto $\mathbf{X}$ de genes para um gene $Y$ por $\sigma_{\mathbf{x}}(Y)$. A força pode ser determinada, por exemplo, pelo coeficiente de determinação ou pela informação mútua. Definimos a força de um conjunto $\mathrm{X}$ de genes para um conjunto de alvos $\mathbf{Y}=Y_{1}, Y_{2}, \ldots, Y_{m}$ de genes por 


$$
\sigma_{\mathbf{x}}(\mathbf{Y})=\Psi\left[\sigma_{\mathbf{x}}\left(Y_{1}\right), \sigma_{\mathbf{x}}\left(Y_{2}\right), \ldots, \sigma_{\mathbf{x}}\left(Y_{m}\right)\right]
$$

onde $\Psi$ é uma função como por exemplo soma, máximo ou mínimo.

Quando o CoD é usado para medir a força de uma conexão, para qualquer variável $Y$ e um conjunto $\mathbf{X}$ de genes, definimos $\sigma_{\mathbf{x}}(Y)=\theta_{\mathbf{x}}(Y)$. No caso da informação mútua, $\sigma_{\mathbf{x}}(Y)=I(\mathbf{X}, Y)^{5}$.

\subsubsection{Algoritmo}

Seguindo o princípio de autonomia [15], deseja-se crescer a rede de maneira a intensificar a força coletiva de conexões entre os genes dentro da subrede. Além disso, também deseja-se limitar a força coletiva das conexões de fora da subrede. Há várias maneiras de anexar medidas de robustez para alcançar esses objetivos.

Seja $\mathbf{S}$ uma subrede e $\mathbf{U}$ o conjunto de todos os genes sob estudo. Os genes que estão no conjunto $\mathbf{U}-\mathbf{S}$, ou seja, os que não foram ainda adicionados à rede, serão chamados de genes candidatos. Seja $Y \in \mathbf{U}-\mathbf{S}$.

$$
\sigma_{d e, \mathbf{S}}(Y)=\sigma_{\mathbf{S}}(Y)
$$

mede a sensibilidade de $Y$ a partir de $\mathbf{S}$, i.e., a força coletiva da conexão a partir da rede $\mathbf{S}$ para o alvo $Y$. Observe que nesse caso todos os preditores de $Y$ estão em $\mathbf{S}$.

$$
\sigma_{p a r a, \mathbf{S}}(Y)=\sigma_{\{Y\} \cup \mathbf{S}}(\mathbf{S})
$$

mede o impacto de $Y$ em $\mathbf{S}$, i.e., a força de conexão do alvo para a rede. Note que a medida $\sigma_{\text {para }, \mathbf{S}}(Y)$ é definida em termos da força de conexão de $\{Y\} \cup \mathbf{S}$, não apenas $Y$. Isto acontece porque estamos interessados na força de conexão de $Y$ quando usada juntamente com outros genes em $\mathbf{S}$, não apenas o próprio $Y$. Para alcançar a autonomia da rede, se $Y$ é um candidato pertencente a $\mathbf{S}$, então $\sigma_{\text {para, }}(Y)$ e $\sigma_{d e, \mathbf{S}}(Y)$ devem ser altos.

As medidas $\sigma_{d e}$ e $\sigma_{\text {para }}$ levam em conta as conexões entre a subrede e genes alvos que devem ser adicionados. Para se alcançar a autonomia da rede, deve ser adicionado um gene $\widehat{Y}$ que satisfaça a condição:

\footnotetext{
${ }^{5} \mathrm{O}$ que aqui for explicado para um dos casos, será facilmente aplicável para o outro caso.
} 


$$
\widehat{Y}=\arg \max _{Y \notin \mathbf{S}} \Xi\left[\sigma_{d e, \mathbf{S}}(Y), \sigma_{p a r a, \mathbf{S}}(Y)\right]
$$

onde $\Xi$ é a função que retorna o valor coletivo para os dois parâmetros e $\widehat{Y}$ maximiza $\Xi$.

Seja $N$ o número máximo de genes que se queira que a rede tenha. Então temos o seguinte algoritmo para o crescimento da rede a partir do conjunto semente $\mathbf{S}$ :

Entrada: $N, \mathbf{S}, \mathbf{U}$

Saída: Rede $\mathbf{G}$ de genes adicionados

$\mathbf{G} \leftarrow \mathbf{S}$

enquanto $\operatorname{card}(\mathbf{G}) \leq N$ faça

$\widehat{Y} \leftarrow \arg \max _{Y \subset \mathbf{U}-\mathbf{G}} \Xi\left[\sigma_{d e, \mathbf{G}}(Y), \sigma_{\text {para }, \mathbf{G}}(Y)\right] ;$

$\mathbf{G} \leftarrow \mathbf{G} \cup\{\widehat{Y}\}$

fim

Algoritmo 1: Algoritmo de crescimento de redes de Dougherty e Hashimoto [15]

\subsection{Modelo de crescimento de redes de E.R. Dougherty e N.W. Trepode}

O modelo de crescimento de redes desenvolvido por Dougherty e Trepode (ainda não publicado) é baseado nas técnicas descritas na subseção anterior. No entanto, alguns critérios foram mudados e algumas condições impostas para tornar mais eficaz o crescimento da rede e aumentar as condições de parada.

Neste modelo, a força de conexão pode envolver mais genes que tenham uma boa relação de predição com o candidato, ou que, com ele, tenha uma boa relação de predição com os genes já adicionados à rede. Quando consideramos a força de conexão $\sigma_{p a r a, \mathbf{S}}$ a partir de um gene candidato, ou a força de conexão $\sigma_{d e, \mathbf{S}}$ para um gene candidato, permitimos que alguns co-preditores ${ }^{6}$ também estejam fora da rede. No primeiro caso, pode ser que todos o co-preditores estejam fora da rede. Já no segundo, pelo menos um deve já estar na rede.

\subsubsection{Força de conexão}

Para cada gene candidato, guarda-se duas listas contendo os grupos de co-preditores envolvidos na força de conexão $\sigma_{d e, \mathbf{S}}$ e $\sigma_{p a r a, \mathbf{S}}$. Como não podemos calcular relações de predição para um número

\footnotetext{
${ }^{6}$ Conjunto de genes envolvidos numa relação de predição.
} 
arbitrário de preditores devido a restrições de pequenas amostras, na prática consideramos:

$$
\sigma_{\mathbf{X}}(Y)=\max _{\mathbf{x} \subset \mathbf{X}, \operatorname{card}(\mathbf{x}) \leq p} \theta_{\mathbf{X}}(Y)
$$

onde o conjunto de genes $x$ é um subconjunto de $X$, de tamanho menor ou igual a $p$ (número máximo de preditores permitido).

A força de conexão de um conjunto $\mathbf{X}$ de genes para um conjunto de alvos $\mathbf{Y}=\left\{Y_{1}, Y_{2}, \ldots, Y_{p}\right\}$ é dada por:

$$
\sigma_{\mathbf{X}}(Y)=\sum_{i=1}^{p} \sigma_{\mathbf{X}}\left(Y_{i}\right)
$$

\subsubsection{Algoritmo}

Como no algoritmo anterior, devemos adicionar à rede um gene $\widehat{Y}$ que satisfaça a condição:

$$
\widehat{Y}=\arg \max _{\widehat{Y} \nsubseteq \mathbf{S}} \Xi\left[\sigma_{d e, \mathbf{S}}(Y), \sigma_{p a r a, \mathbf{S}}(Y)\right]
$$

O impacto de um gene $Y \notin \mathbf{S}$ para a rede $\mathbf{S}$ é dado por

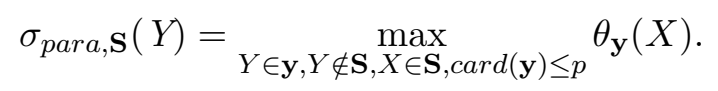

Para cada gene candidato $Y_{i} \notin \mathbf{S}$, definimos

$$
\Xi^{\prime}\left(Y_{i}\right)=\sigma_{d e, \mathbf{S}}\left(\mathbf{y}_{\mathbf{i}}\right)+2 \sigma_{\text {para }, \mathbf{S}}\left(Y_{i}\right)=\sum_{y \in \mathbf{y}_{\mathbf{i}}, y \notin \mathbf{S}} \sigma_{d e, \mathbf{S}}(y)+2 \sigma_{p a r a, \mathbf{S}}\left(Y_{i}\right)
$$

onde $\mathbf{y}_{\mathbf{i}}$ é determinado pela definição de $\sigma_{\text {para }, \mathbf{S}}\left(Y_{i}\right)$ na equação 4.13.

Para os genes candidatos $Y_{i}$ que maximizam $\Xi^{\prime}\left(Y_{i}\right)$, nós incluimos na rede $\mathbf{S}$ os elementos de $\mathbf{y}_{\mathbf{i}}$ - que ainda não estão em $\mathbf{S}$ - e os co-preditores em $\sigma_{d e, \mathbf{S}}\left(\mathbf{y}_{\mathbf{i}}\right)$ - também os que ainda não estão em S. Como não podemos avaliar todas as combinações de co-preditores possíveis, nós realizamos esses cálculos com um subconjunto de "bons candidatos" para $\Xi^{\prime}$ (ou seja, aqueles envolvidos em valores 

altos de predição tanto em $\sigma_{d e, \mathbf{S}}$ quanto em $\left.\sigma_{p a r a, \mathbf{S}}\right)$.

Neste algoritmo, temos duas condições de parada:

1. $\operatorname{card}(S) \geq N$ ou

2. $\frac{\sum_{y \in \mathbf{y}_{\mathbf{i}}, y \notin \mathbf{S}} \sigma_{\mathbf{S}}(y)}{\sum_{y \in \mathbf{y}_{\mathbf{i}}, y \notin \mathbf{S}} 1}<t h_{d e}$ e $\sigma_{p a r a, \mathbf{S}}\left(Y_{i}\right)<t h_{\text {para }}$.

onde $t h_{d e}$ e $t h_{\text {para }}$ são os limiares para os valores médios de predição (CoD ou inf. mútua) de e para a rede. 


\section{Capítulo 5}

\section{Contribuições para o software de estimação e crescimento de redes}

Neste capítulo, iremos descrever o software de N. W. Trepode, que usa a técnica de cálculo de força de predição de PGNs através de CoDs e aplica a teoria do crescimento de redes através de genes sementes, mostrada no capítulo anterior. Falaremos sobre algumas de suas antigas limitações e as modificações feitas para melhorar o processo e a obtenção dos resultados.

\subsection{O software de Nestor Walter Trepode}

Este programa (ainda não publicado) foi desenvolvido por Nestor Walter Trepode durante o período do seu doutorado [19] em que passou no Laboratório de Processamento de Sinal Genômico, na Texas A\&M University, sob a supervisão do Prof. Edward Russell Dougherty. O software (fig. 5.1) é dividido em 5 partes. Na primeira, são calculadas as dependências usando uma quantidade de 1 a $p$ preditores (por trabalharmos com pequenas amostras, $p$ geralmente é igual a 2). A segunda e a terceira partes consistem de eliminar relações de dependência que não são maximais. A quarta parte é simplesmente a preparação desses dados para a aplicação do crescimento de redes, que é a quinta parte do software.

\subsubsection{Estimação das dependências}

Inicialmente, os dados dos genes são pré-processados, como foi explicado na seção 2.2.2. O software trata também amostra com valores faltantes, mas os genes que não têm mais de $70 \%$ das amostras são eliminados. Após isso, para cada gene alvo, para cada combinação de preditores, é criado um arquivo com todas as relações de predição dos outros genes para este. Para cada relação 


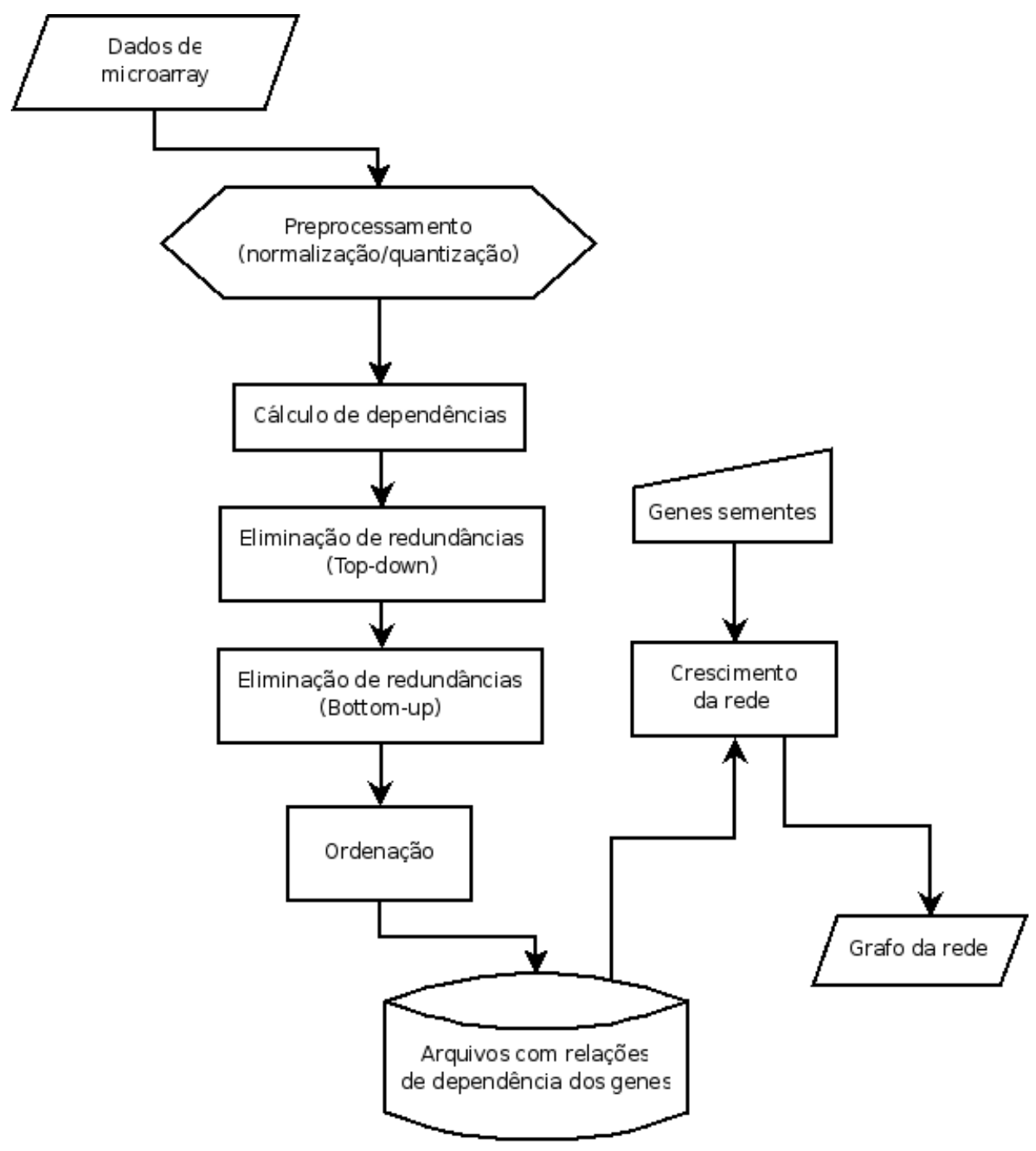

Figura 5.1: Diagrama mostrando as fases de todo o processo de estimação e crescimento de redes gênicas usando o sofware de N.W. Trepode para estimar as dependências. 
de dependência, eram guardadas as seguintes informações:

- o(s) gene(s) preditor(es) e sua(s) respectiva(s) quantidade(s) de instantes de tempo anteriores ao instante de tempo do alvo;

- o erro a priori da predição do alvo por sua média $\left(\varepsilon_{0}\right)$;

- o erro da predição do alvo usando o(s) preditore(s) $\left(\varepsilon_{1,2, \ldots, n}\right)$;

- o valor do CoD;

- o número de amostras usadas no erro a priori e

- o número de amostras usadas no erro usando o(s) preditore(s).

\subsubsection{Eliminação de redundâncias}

A segunda e terceira partes do software comparam conjuntos de genes nas predições para eliminação de redundâncias (retirada de super ou subconjuntos de genes com predição menor). Na eliminação de redundâncias de cima pra baixo (top-down), verifica-se, para cada alvo, se conjuntos de $k$ preditores contém subconjuntos de $k-1$ preditores com relação de dependência maior ou igual. Se isso ocorrer, elimina-se a linha com número $k$ de preditores, pois contem um gene que não agrega valor à predição. Processo semelhante ocorre na eliminação de redundâncias de baixo para cima (bottom-up). Porém, nessa etapa, a linha com menos preditores $(k-1)$ será eliminada, quando o conjunto com $k$ preditores tiver um CoD maior.

\subsubsection{Ordenação dos arquivos}

A quarta parte consiste simplesmente da ordenação decrescente das linhas (usando como critérios primeiramente o valor da dependência, e depois a quantidade de amostras utilizadas para calcular o erro a posteriori, as dependências calculadas usando um número maior de amostras são mais confiáveis) dos arquivos para facilitar o processo de crescimento da rede. Isso é feito usando o algoritmo quicksort.

\subsubsection{Crescimento da rede}

Nessa parte, damos como entrada o conjunto de genes contidos na semente $(\mathbf{S})$ e o conjunto dos genes candidatos $\mathbf{U}-\mathbf{S}$. O resultado final será o conjunto final de genes agregados à rede. O 
algoritmo é o mesmo já apresentado na seção 4.5.2.

\subsection{Limitações do software}

Este programa apresenta algumas limitações que envolvem grande demanda por processamento e armazenamento. Para quantidades muito grandes de genes, o tempo de processamento e o espaço em disco necessário para guardar os dados crescem bastante. Mesmo só guardando valores de dependência relevantes, para cada gene são gravadas em disco milhões de relações de predição. Para cada alvo, deve-se calcular

$$
C_{n t, p}=\left(\begin{array}{c}
n t \\
p
\end{array}\right)=\frac{n t !}{p !(n t-p) !}
$$

onde $n$ é o número total de genes, $t$ é a quantidade máxima de instantes de tempo anteriores ao alvo analisadas, e $p$ a quantidade máxima de preditores a serem utilizados. Para os nossos testes, usamos $n=6532, t=1$ e $p=2$.

\subsection{Aperfeiçoamentos}

Para economizar espaço em disco, retiramos dos arquivos informações redundantes ou não relevantes para o crescimento da rede. Retiramos, de cada linha, os erros a priori e a posteriori, e o número de amostras usadas para o cálculo do erro a priori (como esse valor é o mesmo para cada alvo, guardamos essa informação no cabeçalho do arquivo).

Para compararmos dados obtidos com diferentes medidas de dependência, adaptamos o software para o cálculo de informação mútua com penalização para amostras pouco observadas [10]. O software também foi adaptado para o cálculo de sinal arbitrário (binário, ternário, etc.). Também modificamos o script de gerenciamento e execução das etapas do processo para distribuir o cálculo dos genes em diferentes máquinas. A tabela 5.1 mostra um resumo das modificações e melhorias no programa. 


\begin{tabular}{|c|c|c|}
\hline Processo & Modificações & Detalhes \\
\hline Estimação das dependências & melhorado & $\begin{array}{l}\text { Diminuição do espaço necessário para } \\
\text { armazenamento em disco e cálculo de } \\
\text { CoD ou inf. mútua p/ sinal } n \text {-ário }\end{array}$ \\
\hline Eliminação de redundâncias & adaptado & $\begin{array}{l}\text { Modificação das especificações de entrada } \\
\text { e saída dos dados }\end{array}$ \\
\hline Ordenação dos arquivos & adaptado & $\begin{array}{l}\text { Modificação das especificações de entrada } \\
\text { e saída dos dados }\end{array}$ \\
\hline Gerenciamento das etapas do processo & melhorado & $\begin{array}{l}\text { Paralelização para distribuir o cálculo dos } \\
\text { genes em várias máquinas }\end{array}$ \\
\hline Crescimento de redes de Dougherty e Trepode & adaptado & $\begin{array}{l}\text { Modificação das especificações de entrada } \\
\text { e saída dos dados }\end{array}$ \\
\hline
\end{tabular}

Tabela 5.1: Resumo das modificações no software de N.W. Trepode. 
38CAPÍTULO 5. CONTRIBUIÇÕES PARA O SOFTWARE DE ESTIMAÇÃO E CRESCIMENTO DE REDES 


\section{Capítulo 6}

\section{Algoritmo proposto para crescimento de redes}

Foram mostrados nos capítulos anteriores alguns métodos para modelar redes (redes Boolenas, redes Booleanas probabilísticas e redes gênicas probabilísticas), alguns métodos para estimar, a partir de dados de séries temporais, as dependências entre os genes da rede (coeficiente de determinação e informação mútua) e métodos para a recuperação da arquitetura da rede (o algoritmo de crescimento de redes através de genes sementes de Dougherty e Hashimoto e o de Dougherty e Trepode). Neste capítulo, iremos mostrar um algoritmo de crescimento de redes que, baseado na ideia de caminhos em grafos aleatórios, adiciona genes por camadas de confiança. As sementes iniciais são a camada 0 (zero), e a cada iteração buscamos os genes candidatos mais fortemente relacionados à camada atual, sem precisar verificar novamente relações desses genes candidatos com as camadas anteriores.

\subsection{Avanços do algoritmo proposto em relação aos anteriores}

Como estamos fazendo estimação de predição e em cada uma dessas relações há uma certa taxa de erro (o erro de estimação) envolvida, há uma probabilidade relacionada a cada aresta do grafo. Por isso, usamos aqui a ideia de um grafo aleatório [2,3], que é um tipo de grafo gerado por um processo aleatório. Inicialmente tem-se $n$ vértices e as arestas entre estes vão sendo adicionadas aleatoriamente. O modelo de grafo aleatório mais comum é o de Erdös-Rényi $[2,3]$, chamado $G(n, p)$, em que cada aresta tem a probabilidade $p$ de estar no grafo. Em nosso modelo, no entanto, não sabemos a maneira exata de calcular essas probabilidades, que não tem o mesmo valor. Neste trabalho, uma aresta $v_{i} v_{j}$ irá existir se o gene $v_{i}$ for considerado um bom preditor do gene $v_{j}$. Entretanto, há várias maneiras de se estimar essa relação de predição ( $\mathrm{CoD}$ e inf. mútua, por exemplo) e de se definir o que seria uma boa relação de predição (um valor de corte para a relação, por exemplo). 
Seja $G$ uma rede representada por um grafo aleatório estimado a partir de dados de série temporal, onde os vértices representam genes e as arestas representam relações de dependência. Desejamos, a partir desse grafo (i.e., rede), encontrar a subrede de maior significância em torno das sementes.

Os algoritmos propostos anteriormente precisavam revisitar arestas desse grafo a cada iteração, pois a semente era acumulada e todos os vértices adjacentes a esta deveriam ser verificados novamente. Um método prático pra resolver esse problema sem precisar reestimar cada essas relações de dependência a cada iteração é estimar todas essas relações uma única vez e usar essa informação quando necessário.

Com uma abordagem diferente das anteriores, nosso algoritmo consegue resolver esse problema sem estimar todas as relações de dependência, ou seja, sem precisar construir todo o grafo.

A Fig. 6.1 mostra uma rede com vários genes. Seja $U$ o conjunto de todos os vértices candidatos a entrar na rede. Deseja-se crescer uma subrede $G$ ao redor do gene $\mathbf{A}$, usado como semente, que é a camada inicial, ou 0 (zero). A cada passo, visitamos os vértices adjacentes de qualquer vértice da camada atual, a menos que este já tenha sido adicionado a camadas anteriores.

Partindo do vértice $\mathbf{A}$ (camada 0), inicialmente visitamos B1, B2, B3 e B4. No entanto, apenas os vértices B1, B2 e B4 são adicionados à camada 1 (em azul), devido a sua boa força de predição. As arestas pretas representam as relações verificadas, mas que não contribuiram para adicionar vértices à rede. As arestas azuis representam as relações de predição (a partir da camada 0) que resultaram na adição de um vértice azul para a rede, ou seja, são vértices necessariamente partindo de A. As arestas vermelhas são definidas de forma análoga. São as relações de predição que contribuiram para a adição de um vértice vermelho à rede. Assim, necessariamente eles partem da camada 1, azul. Observe que também é possível vértices de uma mesma camada se visitarem (o caso de B1 e B4, em especial, adiciona uma aresta ao grafo, pois a força de predição entre esses vértices é forte). Dessa forma, podemos identificar relações de predição intra-camadas.

\subsubsection{Diminuição do espaço de busca a cada iteração}

Uma outra observação importante é o fato de que uma aresta do grafo só será visitada se um dos dois vértices for adicionado a alguma camada. Na mesma figura, por exemplo, os vértices adjacentes aos vértices B3 e C5, que não apresentam boa força de conexão com a rede, não serão visitados, a não ser que estejam ligados a vértices do grafo adicionados em camadas posteriores. Quando estamos calculando as relações de predição dinamicamente, a cada camada, isso reduz enormemente 


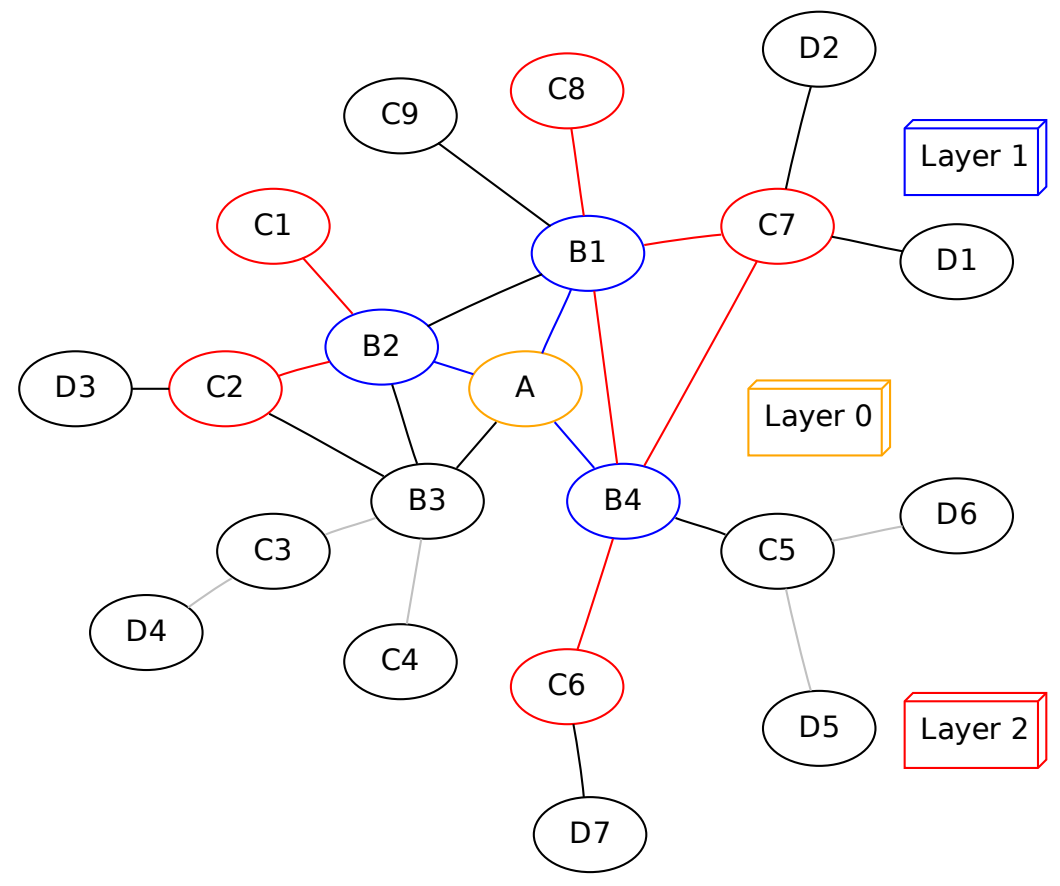

Figura 6.1: Rede mostrando como são visitadas/calculadas as arestas (relações de predição) a cada iteração do algoritmo. $\mathrm{O}$ vértice $\mathrm{A}$, de cor laranja, representada a camada 0 . Os vértices azuis a camada 1 e os vermelhos a camada 2 .

o custo computacional do processo, uma vez que só precisamos calcular as predições (arestas do grafo) partindo da última camada. E a cada vez que um vértice é adicionado a uma camada, ele jamais será visitado novamente no processo, por já terem se esgotado as relações de predição fortes para ele ou a partir dele.

A Fig. 6.2 mostra, para a rede da Fig. 6.1, o crescimento da rede nos algoritmos anteriores e no algoritmo proposto. Os vérices pretos são os candidatos a entrar na rede. Os vértices azuis são a semente da iteração atual. Os vértices cinza são os que não vão ser mais verificados, pois já foram agregados à rede. As arestas pretas são as relações de predição verificadas em cada iteração. As arestas azuis são as que indicam as maiores forças de predição. Logo, os genes candidatos ligados a 
elas devem ser agregados à rede. As arestas cinzas representam relações de predição que não serão calculadas (i.e., arestas que não serão visitadas). A cada iteração, os critérios do algoritmo verificarão se a aresta indicam relações com um certo grau de confiança.

Como foi dito na seção 4.3, o custo de estimar todas as relações de uma rede com $n$ genes e usando apenas $p$ preditores é

$$
n \times C_{n, p}=n \times \frac{n !}{(n-p) ! p !} .
$$

Suponha que queiramos estimar as dependências de uma rede de 1000 genes. Para essa rede, usando apenas 3 preditores, a quantidade de predições estimadas seria

$$
10000 \times \frac{10000 !}{9998 ! 3 !}=\frac{10000 \times 10000 \times 9999 \times 9998}{6} \approx 1,6 \times 10^{15} .
$$

Seja $L_{i}$ a camada a ser usada na iteração $i$ do algoritmo, $G_{i}$ o conjunto de todos os genes já agregados à rede até a $i$-ésima iteração, $k$ a quantidade total de camadas a serem agregadas e $p$ a quantidade de preditores usados em cada relação. O espaço de busca (conjunto de genes a terem sua relação de dependência calculada em relação à rede) da iteração $i$ é $U \backslash G_{i}$ (que contem exatamente $n-\left|G_{i}\right|$ genes), que vai sempre diminuindo (pois $G_{i}$ vai aumentando), até que se termine a execução do algoritmo.

Para cada camada, precisamos calcular quantas relações são estimadas usando a semente como alvos e quantas usando a semente como preditores. Ao usarmos cada semente como um alvo, teremos como preditores todos os vértices de $U-G_{i}$. Ao usarmos cada semente como um preditor, precisamos contabilizar as diferentes quantidades de preditores dentro da camada $L_{i}$. O grupo de alvos, nesse caso, será $U \backslash\left(G_{i} \cup L_{i}\right)$. Assim, temos que o número de relações de predição a serem estimadas para o algoritmo proposto é

$$
\sum_{i=0}^{k-1}[\underbrace{\sum_{j=1}^{p}\left(\begin{array}{c}
L_{i} \\
j
\end{array}\right)\left[n-\left(\left|G_{i}\right|+\left|L_{i}\right|\right)\right]}_{\text {sementes como preditores }}+\underbrace{\left|L_{i}\right|\left(\begin{array}{c}
n-\left|G_{i}\right| \\
p
\end{array}\right)}_{\text {sementes como alvos }}] .
$$




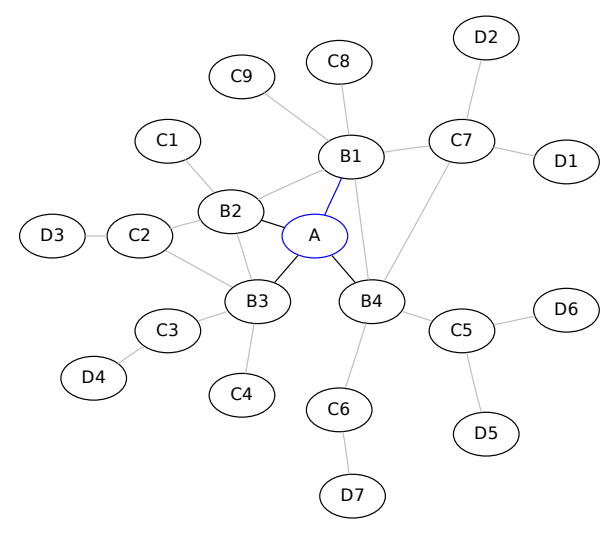

Iteração 0 dos algoritmos antigos

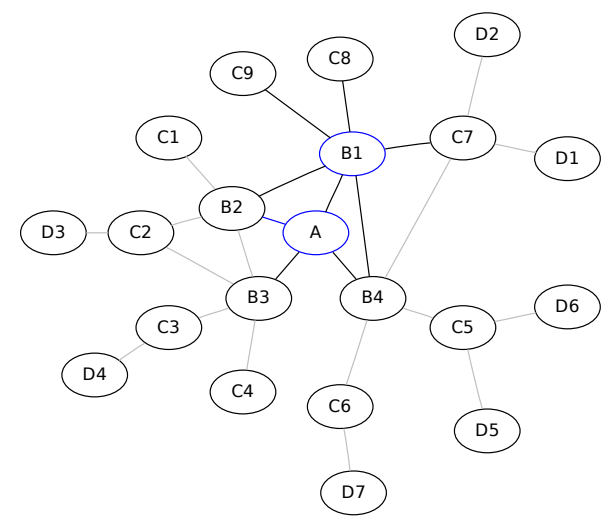

Iteração 1 dos algoritmos antigos

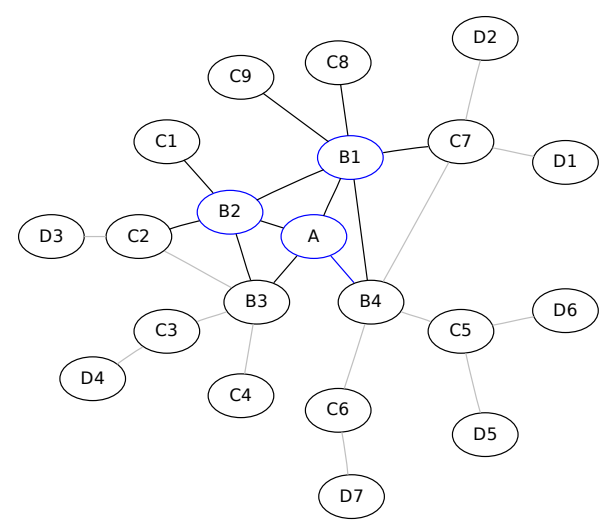

Iteração 2 dos algoritmos antigos

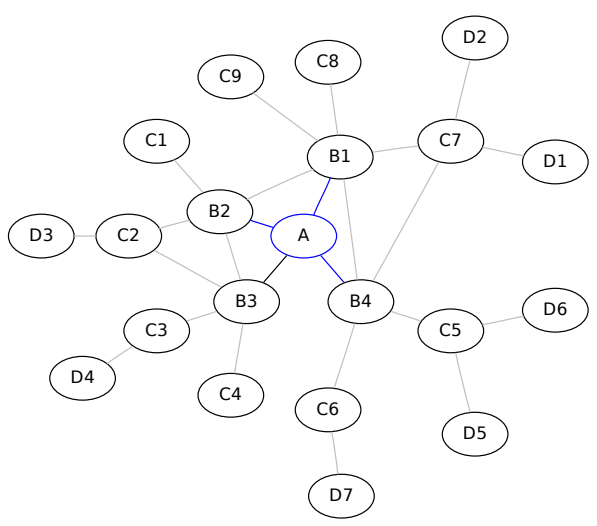

Iteração 0 do algoritmo proposto

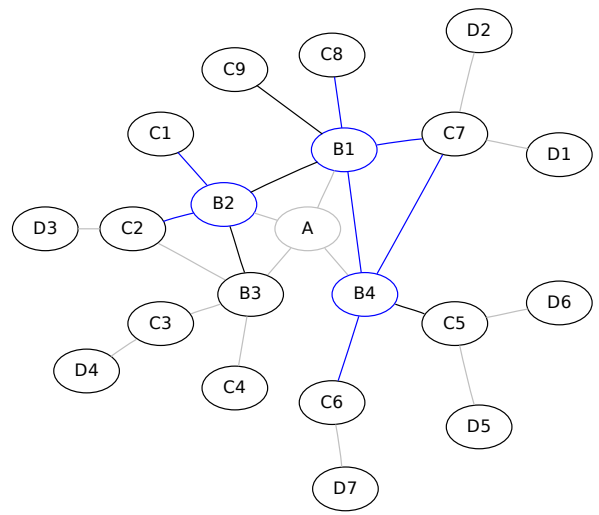

Iteração 1 do algoritmo proposto

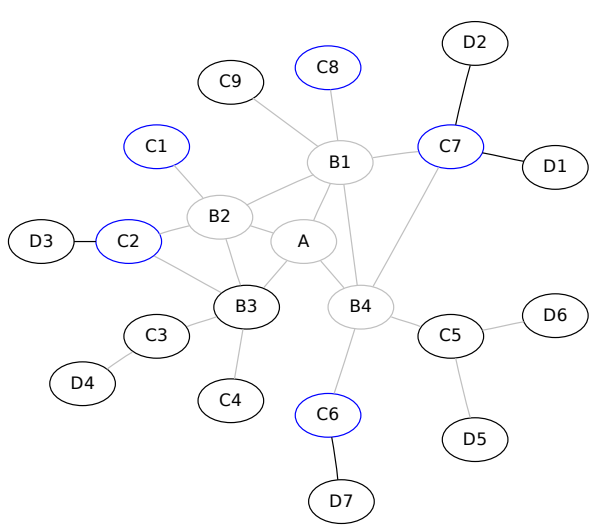

Iteração 2 do algoritmo proposto

Figura 6.2: Sequência de 3 iterações, comparando a busca por genes candidatos, nos algoritmos antigos e no algoritmo proposto. 
Seja $L_{\max }$ a quantidade máxima de genes agregados a alguma camada. Simplificadamente, a Eq. 6.3 representa estimar as relações dos genes de $k$ camadas com no máximo $L_{\text {max }}$ genes. Isso é da ordem de $k \times L_{\max } \times\left(\begin{array}{l}n \\ p\end{array}\right)$. Como $k \times L_{\max }$ geralmente é muito menor que $n$, essa quantidade de estimações será bem menor que todas as estimações possíveis do grafo.

Vamos supor que desejássemos, para os mesmos 10000 vértices (genes) do exemplo anterior, crescer uma rede com 5 camadas, adicionando a cada uma delas no máximo 20 genes e usando $p=3$ preditores. Vejamos a seguir os cálculos para saber a quantidade de predições estimadas no algoritmo proposto:

$$
5 \times 10.000\left[\left(\begin{array}{c}
20 \\
1
\end{array}\right)+\left(\begin{array}{c}
20 \\
2
\end{array}\right)+\left(\begin{array}{c}
20 \\
3
\end{array}\right)\right]+5 \times 10.000 \times\left(\begin{array}{c}
10.000 \\
3
\end{array}\right) \approx 1,6 \times 10^{13} .
$$

O ganho usando o método proposto, nesse exemplo, foi de pelo menos 100 vezes. Na prática, vemos que o uso do crescimento da rede por camadas diminui bastante o custo computacional, pois realmente a quantidade de camadas vezes a quantidade máxima de genes por camada é bem menor que o total de genes.

\subsubsection{Grau de confiança determinado por camadas}

É importante enfatizar que ainda não temos a maneira exata de calcular a probabilidade de cada aresta. Esse é um estudo a ser feito futuramente. Porém, podemos afirmar que a probabilidade de um vértice pertencer à rede é condicionada pela probabilidade de cada vértice do caminho dele à semente inicial pertencer à rede. Na fig. 6.1, por exemplo, a probabilidade de $\mathrm{C} 2$ pertencer à rede depende da probabilidade de B2 pertencer. Da mesma forma o C6 depende do B4 e o C8 depende do B1. Assim, cada camada representa um conjunto de genes com um certo grau de confiança. Quanto mais distante uma camada estiver da semente inicial, menos confiança é dada a ela.

Isso nos faz crer que não seria correto agregar a mesma quantidade de genes a cada camada. Em vez disso, deve-se diminuir esse valor quanto mais se distancia da semente inicial. A cada camada há um valor máximo $\widehat{N}_{i}$ associado, que determina a quantidade máxima de genes que devemos agregar à camada $L_{i}$ de modo que não sejam adicionados genes com o grau de confiança abaixo do valor permitido. Tanto cada $\widehat{N_{i}}$ como o grau de confiança são valores que necessitam de uma análise estatística mais elaborada.

Seja $v_{i}$ um vértice pertencente à camada $i$. E seja $E_{i}$ o conjunto de arestas consideradas como 
boas relações de predição para inserir vértices à camada $i$, ou seja, $\forall i, i=1, \ldots, k-1,\left(v_{i-1}, v_{i}\right) \in E_{i}$. Seja também $\left(v_{0} v_{1} \ldots v_{j}\right), j \leq k-1$, um caminho de um vértice da camada 0 (a inicial) a um vértice de uma camada $j$. Supondo que a probabilidade de todos os genes numa camada terem sido escolhidos seja igual, então a probabilidade de um vértice de uma camada $j$ ser adicionado seria

$$
\operatorname{Pr}\left(\exists v_{0} v_{1} \ldots v_{j}\right)=\prod_{i=1}^{j} \operatorname{Pr}\left(\exists v_{i-1} v_{i}\right),
$$

onde o critério para $\left(v_{i-1}, v_{i}\right) \in E_{i}$ deve ser definido (por exemplo, um limiar, ou uma quantidade máxima de genes a serem agregados à camada $i$, ou os dois critérios simultaneamente).

\subsubsection{Critério para adicionar genes à rede}

Além dessa diferença entre os algoritmos de crescimento de rede anteriores, precisamos citar também que estamos usando outro critério para a escolha das melhores relações de predição entre genes. Na literatura, já foram propostos modelos onde os genes da semente são analisados somente como alvos [10] ou somente como preditores [14]. O modelo de Dougherty e Hashimoto e o de Dougherty e Trepode analisam a semente como preditor e alvo. No entanto, estes dois dão prioridade a genes que tenham um somatório alto de forças como preditor e alvo. No trabalho proposto em [15], a função criada, mostrada na eq. 4.5, pode ser definida como sendo soma, máximo ou mínimo. Porém, nos experimentos feitos nesse mesmo trabalho, a função soma foi utilizada.

No método proposto, agregamos mais valor a genes que tenham pelo menos uma das forças alta, ou seja, buscamos por genes que sejam bons preditores ou bons alvos. Um gene que seja um bom alvo não necessariamente deve ser um bom preditor e vice-versa. Por exemplo, um gene com $\sigma_{d e, S}=0.2$ e $\sigma_{\text {para }, S}=0.9$ no novo algoritmo teria prioridade mais alta que um com $\sigma_{d e, S}=0.6$ e $\sigma_{\text {para }, S}=0.6$, que nos algoritmos antigos seria adicionado primeiro pelo somatório de forças ser 1.2.

A tabela abaixo mostra os dados de uma pequena rede (fig. 6.3) com 5 genes $\left(X_{0}\right.$ a $\left.X_{4}\right)$. São mostradas as relações de dependência entre $X_{0}$ e os outros genes da rede como preditor (força a partir da rede, $\sigma_{d e}$ ) e como alvo (força para a rede, $\sigma_{\text {para }}$ ), e também o somatório e o máximo dessas forças. A tabela 6.1 compara os 3 algoritmos mostrados, indicando que genes seriam agregados à rede, em cada um. 


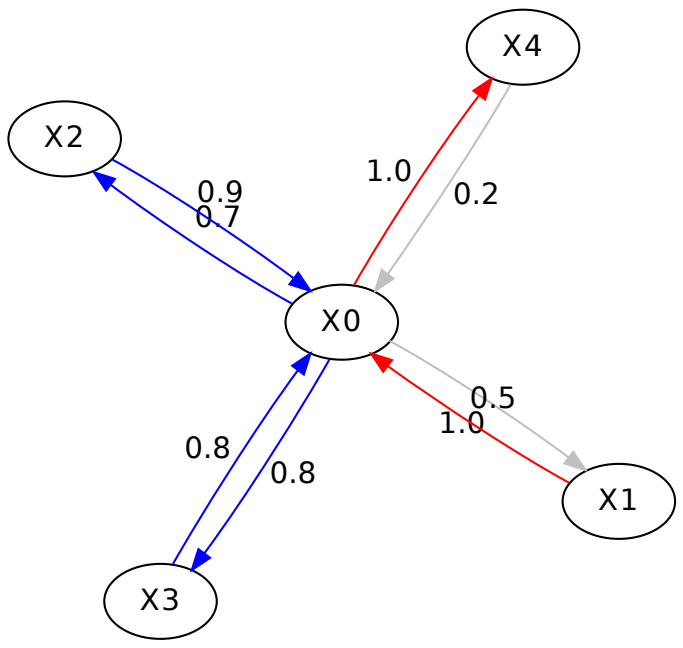

Figura 6.3: Pequena rede com 5 genes e as respectivas relações de dependência (forças de conexão) entre o gene semente $\left(X_{0}\right)$ e o restante da rede. As arestas azuis mostram as relações de predição com prioridade maior, para os métodos de crescimento de redes antigo. As arestas vermelhas indicam as que têm prioridade maior no novo algoritmo.

\begin{tabular}{l|c|c} 
Função utilizada & genes adicionados na $1^{a}$ iteração & sementes da próx. iteração \\
\hline Soma & $X_{2}$ e $X_{3}$ & $X_{0}, X_{2}$ e $X_{3}$ \\
Máximo & $X_{1}$ ou $X_{4}$ & $X_{1}$ e $X_{4}$
\end{tabular}

Tabela 6.1: Tabela mostrando, para a rede de 5 genes, que genes seriam adicionados à rede para cada função utilizada e como ficariam as sementes na próxima iteração.

\begin{tabular}{c|cccc} 
gene & $\sigma_{d e}$ & $\sigma_{\text {para }}$ & $\sum \sigma$ & $\max \sigma$ \\
\hline$X_{1}$ & 0.5 & 1.0 & 1.5 & 1.0 \\
$X_{2}$ & 0.7 & 0.9 & 1.6 & 0.9 \\
$X_{3}$ & 0.8 & 0.8 & 1.6 & 0.8 \\
$X_{4}$ & 1.0 & 0.2 & 1.2 & 1.0
\end{tabular}


Entrada: $S, U, k, t h_{d e}, t h_{p a r a}$

Saída: Conjunto $L$ de camadas de genes e conjunto $E$ das arestas entre as camadas

$L \leftarrow \emptyset ;$

$E \leftarrow \emptyset ;$

$i \leftarrow 0$;

$L_{i} \leftarrow S$

enquanto $L_{i} \neq \emptyset$ e $i<k$ faça

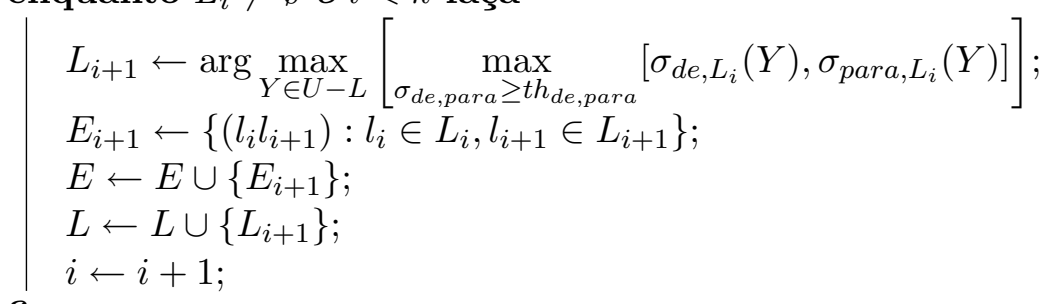

fim

Algoritmo 2: Algoritmo proposto de crescimento de redes por camadas

\subsection{Algoritmo}

No início do algoritmo 2, os genes de $S$ (conjunto de genes sementes) são adicionados a um conjunto $L_{i}$ (camada $i$ ), que conterá os genes a serem analisados na iteração $i$ do algoritmo (inicialmente, $k=0$ e $L_{0}=S$ ). Também é inicializado o conjunto $L$, que deverá conter as camadas, ou seja, é um conjunto de conjuntos. Semelhantemente, é inicializado o conjunto $E$, que contém os conjuntos de arestas (i.e, relações de predição) agregadas à rede a cada passo. A cada iteração, verifica-se, para o conjunto $L_{i}$, quais genes candidatos $Y \in U \backslash L$ têm melhor força de conexão (acima dos devidos limiares) para $L_{i}$ ou a partir de $L_{i}$. Estes, juntamente com os co-preditores relacionados, serão adicionados ao conjunto $L_{i+1}$. Esses genes servirão como sementes para a próxima iteração do algoritmo, que prosseguirá enquanto houver genes na camada $L_{i}$ (ou seja, que na iteração anterior pelo menos um gene tenha obedecido aos critérios de agregação) e enquanto a quantidade de camadas necessárias não chegar ao seu limite $(k)$. Ao final, a rede será a união de todos os conjuntos de $L$ com as devidas arestas nos conjuntos de $E$.

\subsection{Implementação do algoritmo proposto}

Foi implementada em Python uma versão do algoritmo proposto. O programa gera o grafo de dependências com a rede final crescida a partir das sementes dadas. Ele rotula os vértices com o nome do gene correspondente e os colore de acordo com a classificação funcional dos mesmos (retirados 
de http://www.vision.ime.usp.br/camda04/). Relações de predição a partir dos mesmos genes co-preditores têm as arestas de mesma cor. Genes adicionados à rede na mesma camada (conjunto $\left.L_{i}\right)$ têm borda externa de mesma cor (indicada nas figuras por "Layer"). 


\section{Capítulo 7}

\section{Resultados experimentais}

Neste capítulo falaremos sobre como foi feita a comparação do algoritmo proposto com outro método já conhecido, usado durante o CAMDA (Critical Assessment of Microarray Data Analysis) em 2004 em dados do Plasmodium falciparum, parasita da malária.

\subsection{Experimentos do CAMDA}

O CAMDA é uma conferência proposta inicialmente pelo grupo de pesquisas em bioinformática da Universidade de Duke, nos EUA. Seu propósito é estabelecer um fórum de diferentes técnicas para interpretação de dados de microarray. Em cada edição, é proposto um conjunto de dados e vários grupos de pesquisa de todo o mundo submetem seus métodos de análise desses dados.

Em 2004, foi proposta a análise dos dados gerados pela equipe de Joseph DeRisi [21], correspondente ao estágio do ciclo de vida do parasita no sangue humano (que tem a duração de aprox. 48h). Os dados eram 48 amostras, formando um sinal temporal de 6532 genes do Plasmodium falciparum, com intervalos de 1h. O grupo vencedor [10] usou o método das Redes Genéticas Probabilísticas com informação mútua para estimar a arquitetura da rede.

Primeiramente, foram usados genes sementes que codificavam as 10 enzimas pertencentes à via metabólica da glicólise, que é responsável pela produção de ATP durante o estágio de reprodução assexuada do parasita no sangue humano. A partir desses genes dados como rede inicial, foram agregados para cada um, os melhores grupos de preditores. Com esse experimento, conseguiu-se adicionar à rede uma grande quantidade de genes relacionados à glicólise.

Também foram realizados testes com genes relacionados ao apicoplasto, uma organela descoberta 
recentemente no filo Apicomplexa [12]. As enzimas do apicoplasto vêm sendo usadas como novos alvos de vacina pelo fato de a organela não ter uma homóloga no hospedeiro humano. Novamente, foram escolhidos alguns genes como sementes, e agregados os melhores grupos de preditores. Os resultados conseguiram comprovar mais uma vez que o método é capaz de adicionar genes relacionados.

Sabe-se que a glicólise e o apicoplasto são fundamentais para o desenvolvimento do parasita, mas suas funções dentro do organismo não têm nenhum tipo de relação direta. Também foram feitos experimentos crescendo a rede simultaneamente de genes da glicólise e apicoplasto, e a rede crescida ficou praticamente disjunta, dividida entre o grupo de genes relacionados ao apicoplasto e o grupo de genes relacionados à glicólise. Foi observado também que genes de apicoplasto tendem a se unir mais fortemente que genes de glicólise.

\subsection{Experimentos com algoritmo proposto}

Para verificarmos o desempenho do algoritmo proposto usando dados reais, fizemos alguns experimentos similares aos experimentos realizados no CAMDA. Redes crescidas a partir de genes sementes relacionados ao apicoplasto ou glicólise tiveram a tendência a recuperar grupos de genes com mesma função. As Figuras 7.1 e 7.2 mostram rede de duas camadas crescidas a partir de sementes da glicólise. A rede da Fig. 7.1 foi crescida adicionando os 10 melhores grupos de candidatos (alvos, pares de preditores, ou preditores únicos), e a rede da Fig. 7.2 adicionando os 20 melhores. É interessante notar que quase todos os genes da semente se ligam, seja com genes alvos em comum ou com preditores em comum.

A Fig. 7.3 mostra uma pequena rede crescida com sementes do apicoplasto. Novamente, todas as sementes se interligaram de alguma forma. É interessante notar o aparecimento de genes atratores, que são alvos de vários grupos de genes simultanemente, na rede. A Fig. 7.4 mostra uma rede crescida a partir de 4 genes de glicólise e 4 genes de apicoplasto. É importante notar que aqui, como os critérios de agregação de genes é diferente dos critérios do CAMDA, há genes na semente inicial que não se ligam a ninguém. Isso acontece porque os preditores ou alvos desses genes não estão entre os melhores da rede. Nessa rede da Fig. 7.4, por exemplo, quase todos os genes da camada 1 estão agregados a um só gene da semente (camada 0 ).

A Fig. 7.5 apresenta um rede crescida a partir de um gene de apicoplasto. O objetivo era recuperar o único melhor preditor ou alvo, ou todos que empatarem nessas condições. Observe que a camada 1 incluiu somente 2 genes (um alvo, "F13784_1", e um co-preditor, "C41"). A camada 2, no entanto, 
agregou quase 30 genes, entre preditores e alvos. De forma parecida, na rede da Fig. 7.6 usamos somente uma semente de apicoplasto e foram geradas 3 camadas. A camada 1 só agregou 2 genes, mas na camada 2 , dentre todos os que entraram empatados com força máxima, foram recuperados 6 outros relacionados à glicólise.

Essas e mais alguma figuras estão disponíveis no site http://www.vision.ime.usp.br/ llima/ mestrado/figuras/ com maior qualidade.

Fizemos outros testes com poucos genes sementes e pelo menos 3 camadas. No entanto, essas redes cresceram acima do esperado, pelo fato de serem incluídos todos os genes que estejam empatados em todos os critérios usados. Nesse trabalho, usamos como critérios o valor da relação de dependência e o número de amostras utilizadas na estimação a posteriori. 


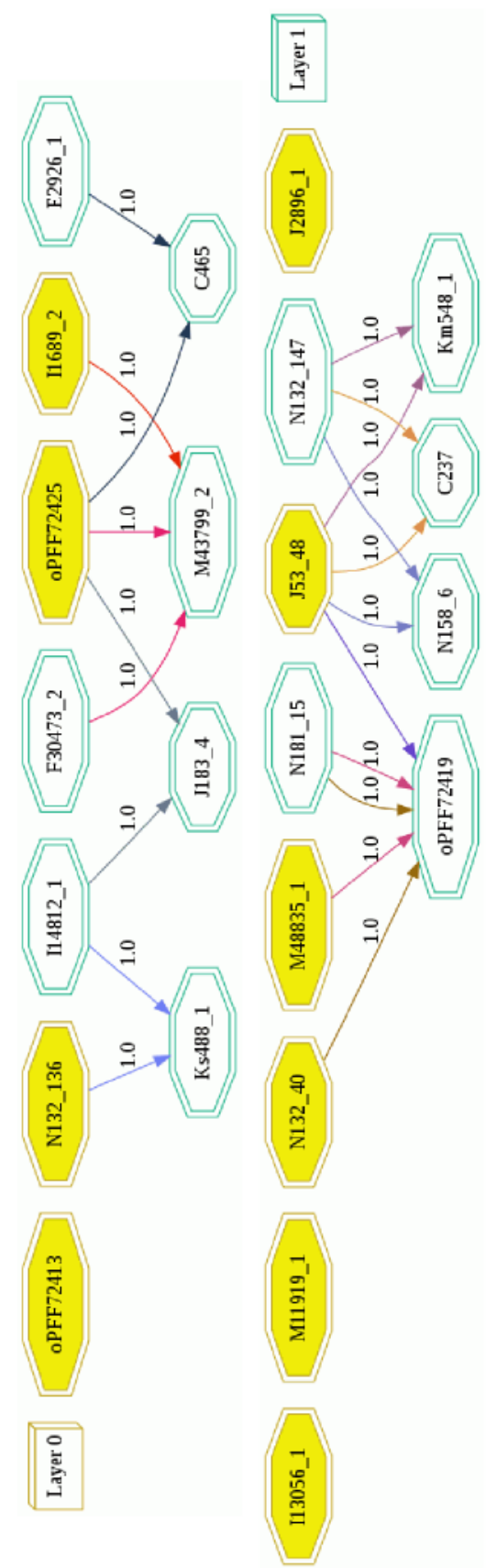

Figura 7.1: Grafo gerado pelo software de crescimento de redes a partir de sementes da glicólise (amarelos), usando 2 camadas e agrupando os 10 melhores grupos. 


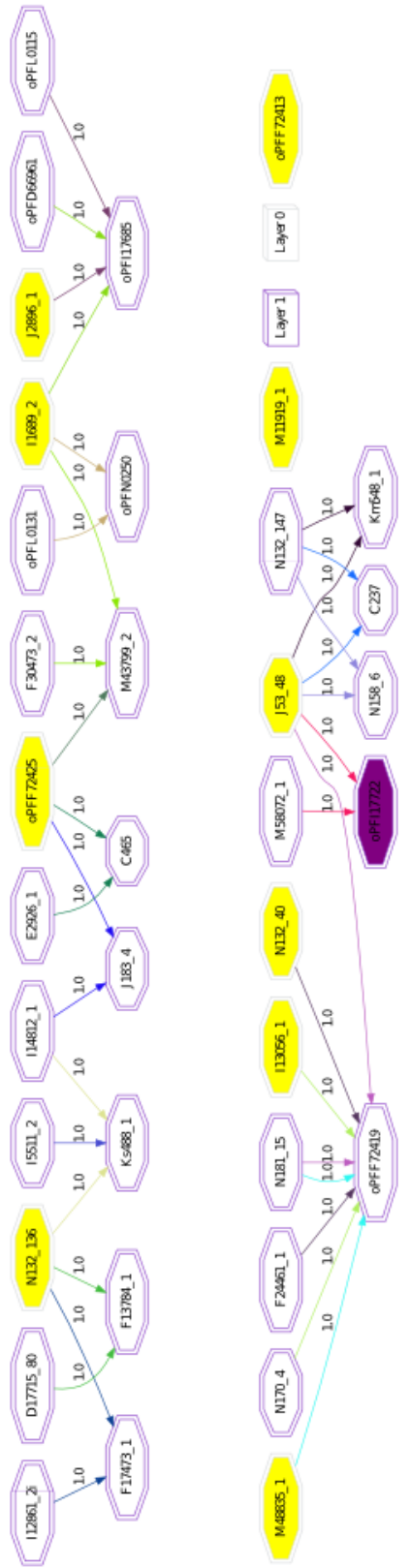

Figura 7.2: Rede crescida a partir de sementes da glicólise, usando 2 camadas e agrupando os 20 melhores grupos. 


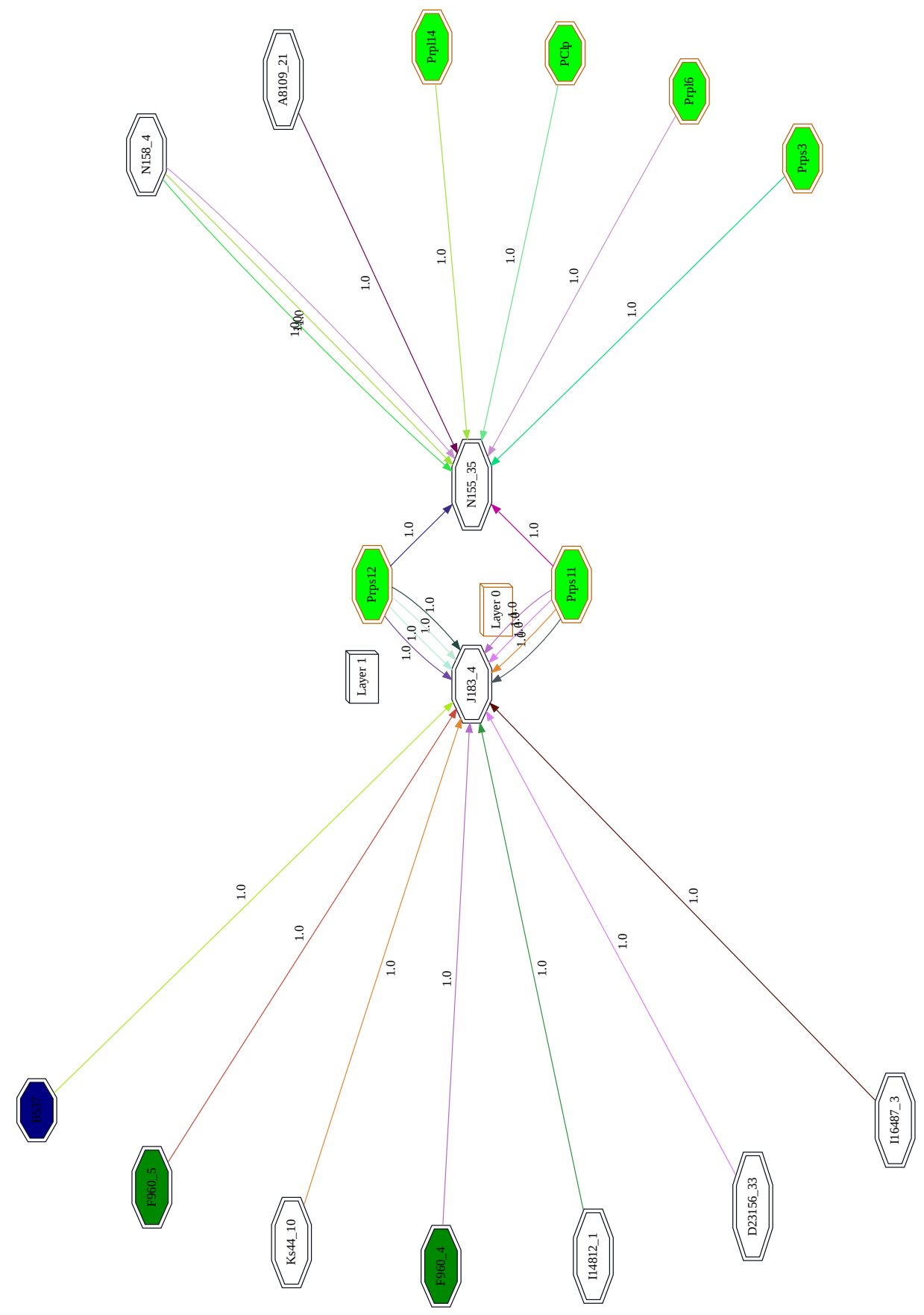

Figura 7.3: Rede crescida a partir de sementes do apicoplasto (verdes). Aqui, como em alguns outros grafos gerados, houve o aparecimento natural de genes atratores. 


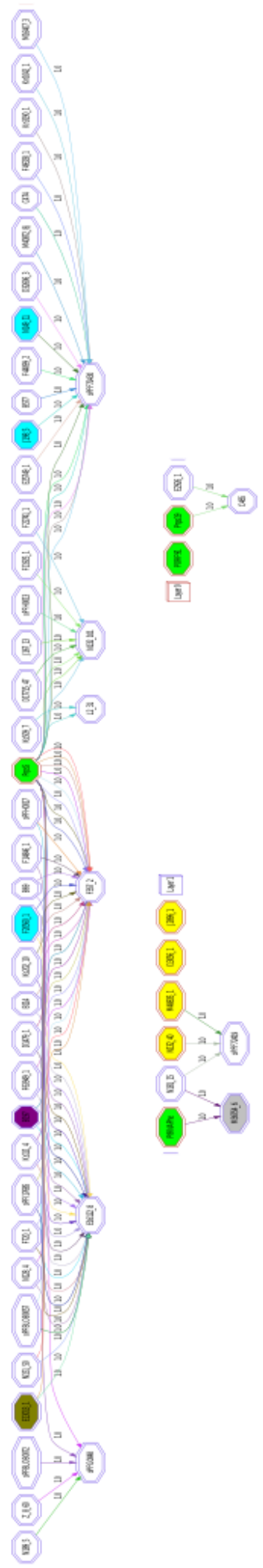

Figura 7.4: Rede crescida a partir de sementes da glicólise (amarelos) e do apicoplasto (verdes). Vemos aqui que genes de apicoplasto tendem a ter ligações mais fortes entre si e com o restante da rede. 


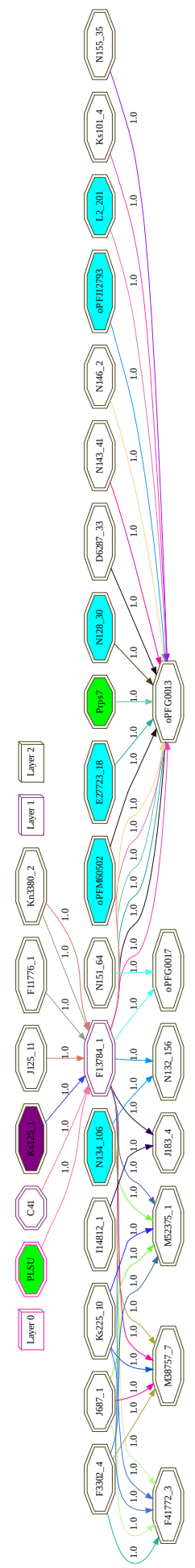

Figura 7.5: Rede crescida a partir de uma semente do apicoplasto ("PLSU"), com 3 camadas, e melhores empatados sendo agregados. Observe que a camada 1 só contem dois genes, e somente um deles foi o responsável por agregar todos os genes da camada 2 ("C41" e "F13784_1"), que conseguiu recuperar um outro gene de apicoplasto ("Prps7"). 


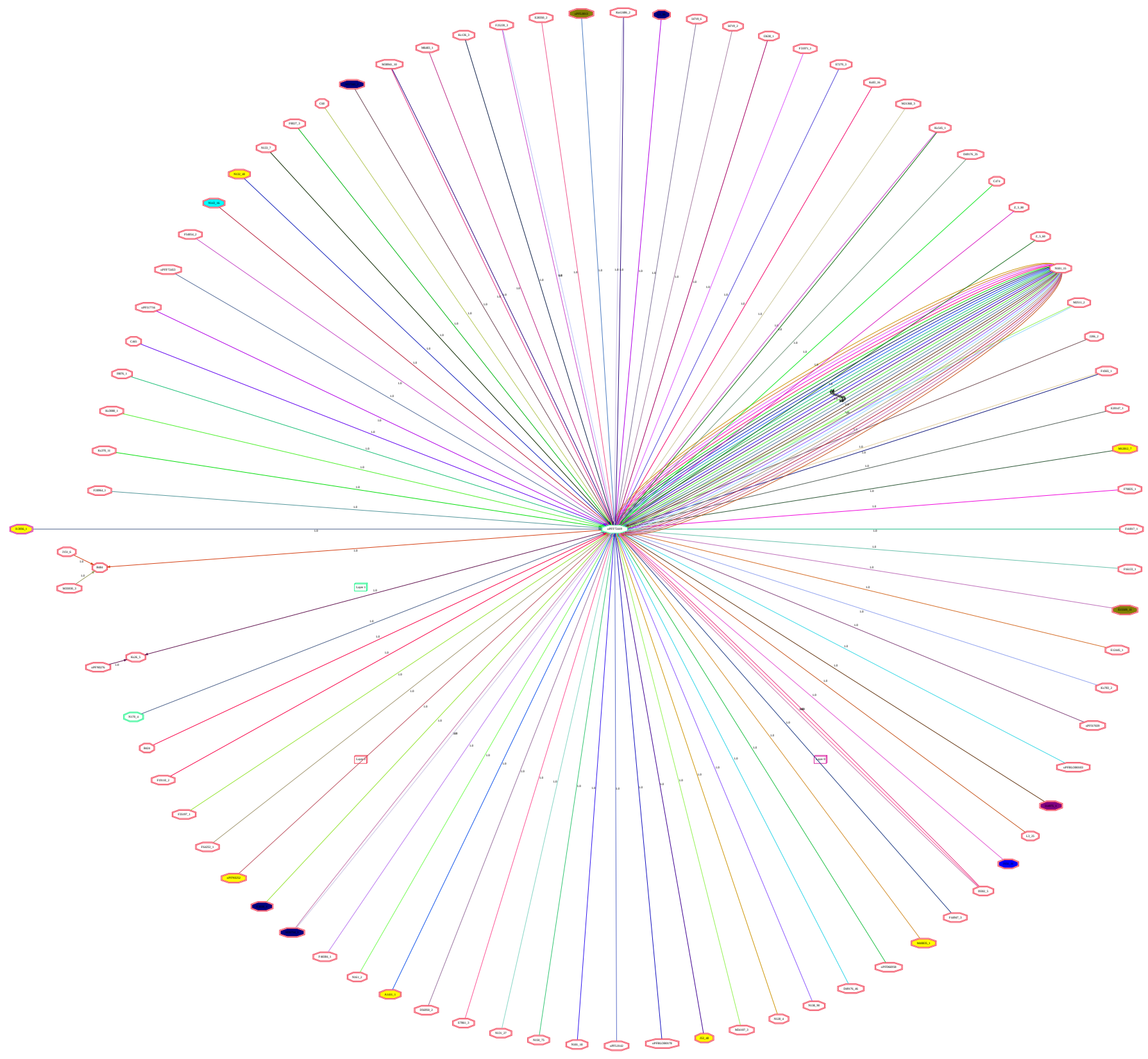

Figura 7.6: Rede crescida a partir de uma semente do glicólise (genes "I13056_1", mais à esquerda da rede), com 3 camadas, e melhores empatados sendo agregados. Como na Fig. 7.5, somente dois genes foram agregados à segunda camada (um deles o gene central da figura, "oPFF72419"). Podemos observar aqui que na terceira camada, de número 2 , seis outros genes da glicólise foram recuperados. 


\section{Capítulo 8}

\section{Conclusões}

Foram mostradas algumas formas para modelar redes de regulação gênica. Devido a características específicas dos tipos de dados, que são medidas temporais de microarray, escolhemos um método discreto e estocástico para modelar as redes gênicas. Tendo sido escolhido o modelo, as redes genéticas probabilísticas, mostramos dois métodos para estimar as relações de predição entre os genes. Foi mostrado que essas redes, modeladas como grafos, têm um valor de probabilidade associado a cada aresta, já que os métodos para estimar essas forças de conexão envolvem erro, incerteza.

Foram estudados métodos para crescimento de redes através de genes sementes. Nesses métodos, dá-se prioridade a genes que têm um bom somatório de forças como preditores e alvos conjuntamente, e a cada iteração as sementes são acumuladas. A cada passo, reestimam-se as relações de predição para a rede e a partir dela pra todo o restante da rede novamente. Para se poupar processamento, calcula-se uma vez todas as predições entre os genes da rede.

Foi proposto nesse trabalho um algoritmo que agrega genes por sua força máxima como preditores das sementes ou como alvos dessas. Esse método leva em consideração que genes bons preditores ou bons alvos das sementes (não necessariamente as duas coisas juntas) devem ser incluídos na rede. Outra vantagem do algoritmo proposto é que este descarta relações de predição envolvendo genes já adicionados à rede. A partir das sementes iniciais, o algoritmo cresce a rede esgotando todas as possibilidades de bons genes relacionados a essas. Para cada passo, os últimos genes agregados se tornam sementes e o algoritmo não mais olha para os que já foram adicionados. Esses grupos de genes agregados a cada iteração, chamados de camadas, representam conjuntos com grau de confiança

diferenciados. À medida que um gene é agregado mais distante das sementes iniciais, menos confiança deve ser dada a eles. 
Também foram feitas melhorias no software de estimação de redes gênicas usando redes genéticas probabilísticas de N.W. Trepode, para que melhorasse o uso do espaço em disco e possibilitasse a estimação das relações de predição usando informação mútua. Também foi implementado o algoritmo proposto, que usa os dados estimados pelo software de Trepode. O programa gera a rede com o número escolhido de camadas e constrói o grafo correspondente com o auxílio da ferramenta Graph Viz.

Para validar o software, usamos dados do ciclo assexuado do sangue humano do Plasmodium falciparum, parasita da malária. Utilizando algumas sementes de apicoplasto ou glicólise, foi possível construir redes que recuperaram genes de mesma função. Utilizando sementes escolhidas aleatoriamente, em geral conseguiu-se recuperar grande parte dos genes nas camadas mais próximas às sementes iniciais. Um dos problemas que tivemos que ao agregarmos genes à rede, várias vezes apareceram muitos genes empatados. Os critérios para desempate foram primeiramente o valor de predição e em seguida a quantidade de amostras usadas na estimação a posteriori.

Para trabalhos futuros, há aspectos relacionados aos parâmetros utilizados e aspectos relacionados ao software. Para tratar o problema dos desempates, podemos estudar outros critérios para diferenciar os genes, como a entropia da distribuição a priori de cada um. Desse forma, poderíamos dar prioridade aos que tivessem maior nível de atividade. No que diz respeito às camadas, há ainda que se fazer um estudo estatístico aprofundado para estimar os parâmetros corretos para o crescimento da rede, como:

1. a quantidade de camadas correta, para não agregarmos à rede genes de baixa confiança, e

2. a quantidade de genes agregados em cada camada, tendo em mente que essa quantidade vai decaindo, a cada camada.

Em relação ao software, pretendemos disponibilizá-lo na internet de forma a facilitar o seu uso e análise principalmente profissionais das áreas biológicas. Estão surgindo diversas ferramentas para pesquisa com redes gênicas. Em parceria com outro grupo que estuda a criação de um ambiente web colaborativo para padronizar esse tipo de ferramenta, pretendemos agregá-lo a esse projeto. 


\section{Referências Bibliográficas}

[1] Seungchan Kim Edward R. Dougherty and Yidong Chen, Coefficient of determination in nonlinear signal processing, Signal Processing 80 (2000), no. 10, 2219-2235.

[2] Paul Erdös and Alfréd Rényi, On random graphs, i, Publicationes Mathematicae (Debrecen) 6 (1959), 290-297.

[3] _ On the evolution of random graphs, Publ. Math. Inst. Hung. Acad. Sci 5 (1960), 17-61.

[4] Iiris Hovatta et al, Dna microarray data analysis, CSC - Scientific Computing Ltd., 2005.

[5] Edward R. Dougherty João Eduardo Ferreira Marco Dimas Gubitoso Hugo Aguirre Armelin, Junior Barrera and Eduardo Jordão Neves, Simulator for gene expression networks, SPIE Microarrays: Optical Technologies and Informatics, vol. 4266, 2001, pp. 248-259.

[6] Seungchan Kim Ilya Shmulevich, Edward R. Dougherty and Wei Zhang, Probabilistic boolean networks: a rule-based uncertainty model for gene regulatory networks, Bioinformatics 18 (2001), no. 2, 261-274.

[7] Hidde De Jong, Modeling and simulation of genetic regulatory systems: a literature review, Journal of Computational Biology 9 (2002), no. 1, 67-103.

[8] David Correa Martins Junior, Seleção de características e predição intrinsecamente multivariada em identificação de redes de regulação gênica, Ph.D. thesis, Universidade de São Paulo, São Paulo, SP, 2008.

[9] Daniel Oliveira Dantas David Correa Martins Jr Nestor Walter Trepode Junior Barrera, Roberto Marcondes Cesar Jr, From microarray images to biological knowledge, II Simpósio Brasileiro de Biologia Matemática e Computacional, 2002, pp. 210-239.

[10] David Correa Martins Jr Ricardo Z. N. Vêncio Emilio F. Merino Márcio M. Yamamoto Florencia G. Leonardi Carlos A. de B. Pereira Junior Barrera, Roberto Marcondes Cesar Jr and Hernando A. Del Portillo, Methods of microarray data analysis v, chapter 2: Constructing probabilistic genetic networks of plasmodium falciparum from dynamical expression signals of the intraerythrocytic development cycle, pp. 11-26, 2007. 
[11] S. A. Kauffman, Metabolic stability and epigenesis in randomly constructed genetic nets, Journal of Theoretical Biology 22 (1969), no. 3, 437-467.

[12] Eric Maréchal and Marie-France Cesbron-Delauw, The apicoplast: a new member of the plastid family, Trends in Plant Science 6.

[13] Hilmar Lapp Norbert Brändle, Horst Bischof, Robust dna microarray image analysis, Machine Vision and Applications 15 (2003), no. 1, 11-28.

[14] Marcelo Ris, Representação de sistemas biológicos a partir de sistemas dinâmicos: controle da transcrição a partir do estrógeno, Ph.D. thesis, Universidade de São Paulo, São Paulo, SP, 2008.

[15] Ilya Shmulevich Wei Zhang Michael L. Bittner Edward R. Dougherty Ronaldo F. Hashimoto, Seungchan Kim, Growing genetic regulatory networks from seed genes, Bioinformatics 20 (2004), no. $8,1241-1247$.

[16] M. L. Bittner Y. Chen K. Sivakumar P. Meltzer Seungchan Kim, Edward R. Dougherty and J. M. Trent, A general nonlinear framework for the analysis of gene interaction via multivariate expression arrays, Journal of Biomedical Optics 5 (2000), no. 4, 411-424.

[17] Claude E. Shannon, A mathematical theory of communication, The Bell System Technical Journal 27 (1948), 279-423, 623-656.

[18] Joy A. Thomas Tomas M. Cover, Elements of information theory, John Wiley \& Sons, New York, NY, 1991.

[19] Nestor Walter Trepode, Modelagem do controle gênico do ciclo celular por redes genéticas probabilísticas, Ph.D. thesis, Universidade de São Paulo, São Paulo, SP, 2007.

[20] Ricardo Zorzetto Nicoliello Vêncio, Análise estatística na interpretação de imagens: microarranjos de dna e ressonância magnética funcional, Ph.D. thesis, Universidade de São Paulo, São Paulo, SP, 2006.

[21] Brian Lee Pulliam Edith D. Wong Jingchun Zhu Zbynek Bozdech, Manuel Llinas and Joseph L. DeRisi, The transcriptome of the intraerythrocytic development cycle of plasmodium falciparum, PLoS Biology 1 (2003), no. 1. 